\title{
Concurrent hippocampal induction of MHC II pathway components and glial activation with advanced aging is not correlated with cognitive impairment
}

Heather D VanGuilder ${ }^{1}$, Georgina V Bixler', Robert M Brucklacher ${ }^{1}$, Julie A Farley², Han Yan², Junie P Warrington², William E Sonntag ${ }^{2}$ and Willard M Freeman ${ }^{1 *}$

\begin{abstract}
Background: Age-related cognitive dysfunction, including impairment of hippocampus-dependent spatial learning and memory, affects approximately half of the aged population. Induction of a variety of neuroinflammatory measures has been reported with brain aging but the relationship between neuroinflammation and cognitive decline with non-neurodegenerative, normative aging remains largely unexplored. This study sought to comprehensively investigate expression of the MHC II immune response pathway and glial activation in the hippocampus in the context of both aging and age-related cognitive decline.

Methods: Three independent cohorts of adult (12-13 months) and aged (26-28 months) F344xBN rats were behaviorally characterized by Morris water maze testing. Expression of MHC II pathway-associated genes identified by transcriptomic analysis as upregulated with advanced aging was quantified by $\mathrm{qPCR}$ in synaptosomal fractions derived from whole hippocampus and in hippocampal subregion dissections (CA1, CA3, and DG). Activation of astrocytes and microglia was assessed by GFAP and Iba1 protein expression, and by immunohistochemical visualization of GFAP and both CD74 (Ox6) and Iba1.
\end{abstract}

Results: We report a marked age-related induction of neuroinflammatory signaling transcripts (i.e., MHC II components, toll-like receptors, complement, and downstream signaling factors) throughout the hippocampus in all aged rats regardless of cognitive status. Astrocyte and microglial activation was evident in CA1, CA3 and DG of intact and impaired aged rat groups, in the absence of differences in total numbers of $\mathrm{GFAP}^{+}$astrocytes or $\mathrm{Iba}^{+}$ microglia. Both mild and moderate microglial activation was significantly increased in all three hippocampal subregions in aged cognitively intact and cognitively impaired rats compared to adults. Neither induction of MHCII pathway gene expression nor glial activation correlated to cognitive performance.

Conclusions: These data demonstrate a novel, coordinated age-related induction of the MHC II immune response pathway and glial activation in the hippocampus, indicating an allostatic shift toward a para-inflammatory phenotype with advancing age. Our findings demonstrate that age-related induction of these aspects of hippocampal neuroinflammation, while a potential contributing factor, is not sufficient by itself to elicit impairment of spatial learning and memory in models of normative aging. Future efforts are needed to understand how neuroinflammation may act synergistically with cognitive-decline specific alterations to cause cognitive impairment.

Keywords: hippocampus, cognitive decline, para-inflammation, neuroinflammation, aging, Morris water maze

\footnotetext{
* Correspondence: wfreeman@psu.edu

'Department of Pharmacology, Pennsylvania State University College of

Medicine, 500 University Drive, Hershey, Pennsylvania, 17057, USA

Full list of author information is available at the end of the article
} 


\section{Background}

Cognitive aging, characterized by a decline in a range of cognitive functions central to independence and quality of life, affects more than half of the population over 60 years of age [1]. Spatial learning and memory is one of the domains of cognitive function most frequently and severely impacted with aging [2]. Spatial cognitive function is mediated, to a large extent, by the hippocampus, which undergoes numerous molecular and physiological changes with aging. These alterations include vascular rarefaction, decreased trophic support, decreased glucose utilization and bioenergetic metabolism, and impaired protein synthesis and quality control (reviewed in [3]). Additionally, with advancing age, hippocampal volume decreases and neurotransmission and synaptic integrity decline, all in the absence of gross neuronal loss or overt neuropathology [4-9]. The molecular and cellular basis of these changes may include misfolded proteins and protein aggregates [10], synaptic pruning [11], decreased synaptic protein expression [12], and increased oxidative stress [8], which together suggest that the neural microenvironment becomes dysregulated in the aged hippocampus. This dysregulation may indicate a declining ability of glial cells to perform their roles in debris clearance, nutritional support, and even neurotransmission, which are vital for maintenance of hippocampal function and hippocampusdependent spatial learning and memory [13-16].

The glial shift toward an activated phenotype with normal aging likely reflects increased inflammatory signaling, which has been implicated in damage- and disease-related cognitive impairment as discussed below. Pathological gliosis and inflammation are associated with severe cognitive dysfunction in neurodegenerative/advanced disease states (e.g., Alzheimer's disease, vascular dementia), traumatic brain injury, chronic stress and direct inflammatory stimulation (e.g., lipopolysaccharide injection, transgenic manipulation) [17-24]. Deficits of hippocampus-dependent cognitive function with healthy aging are less severe and more heterogeneous, affecting a subset of the aging population while others retain normal cognitive capabilities. Rodent models of normative human aging reflect this behavioral heterogeneity, which enables segregation of aged animals into cognitively intact and cognitively impaired groups and assessment of both age-related and cognitive impairment-specific phenomena [25-27]. Glial activation and induction of inflammatory response factors are recognized components of normal brain aging, but characterization of hippocampal cellular and molecular mediators of immune/inflammatory signaling in cognitively stratified subjects remains incomplete. Studies of severe neurodegenerative conditions characterized by significant neuronal loss suggest that neuroinflammation is a causative factor in cognitive impairment $[28,29]$. The relationship between neuroinflammatory signaling and non-neurodegenerative age-related cognitive decline, however, is not understood, and is likely less straightforward than that observed with neurodegenerative conditions.

Here, we demonstrate the age-related induction of 21 inflammation-response genes including MHC II antigen processing components, antigen-recognizing receptor pathways, immune cell activating factors, and downstream inflammatory signaling molecules in whole-hippocampus synaptosomal fractions and in discrete hippocampal subregions (CA1, CA3, DG) derived from independent cohorts of rats behaviorally assessed for hippocampus-dependent learning and memory by Morris water maze testing. MHC II signaling has a pivotal role in immune responses and inflammation, responding to both exogenous (e.g., bacterial) and endogenous (e.g., protein aggregates, necrotic cell debris) antigenic proteins. These antigenic proteins bind to molecules including toll-like receptors (Tlr2, Tlr4, Tlr7) and complement components (C1s, C3, C4a, Serping1 [C1inh]), which recognize potentially threatening peptide sequences classified as PAMPs (pathogen-associated molecular patterns) and DAMPs (danger-associated molecular patterns). Recognition of these sequences stimulates immune cell-activating factors (Erbb3, Ccr5, Fcgr2a, $F c g r 2 b)$ and internalization of the protein, processing, and subsequent presentation by MHC II (for review see [30] and [31]). The MHC II complex consists of alpha and beta chains (Hla-Dra and Hla-Drb), which heterodimerize to form an antigen binding pocket. This pocket is typically blocked by a cathepsin (Ctse)-cleaved peptide product of Cd74, called CLIP (i.e., the MHC II invariant chain), which prevents spontaneous binding of self-derived peptides. An MHC II cofactor consisting of its own alpha and beta chain subunits $(H l a-D m)$ facilitates removal of CLIP and loading of the antigenic peptide prior to MHC II trafficking to the membrane for presentation to immuneresponse cells.

In the central nervous system, microglia constitute the primary line of immunity and defense, and as such, are the primary mediators of MHC II antigen processing and presentation, whereas MHC II is typically expressed only at nominal levels in astrocytes in vivo [32,33]. Toll-like receptors and complement components, as well as downstream inflammatory signaling factors ( Hsbp1, Lgals3, Cp, Icam1, S100a6), on the other hand, are more broadly expressed by astrocytes, microglia and neurons In the CNS, both microglia and astrocytes play regulatory and supportive roles in neuronal function by metabolizing glutamate, providing nutritional support, and removing potentially toxic cell debris $[15,34,35]$ In the aged hippocampus, cellular debris detected by activated microglia and astrocytes may include degenerating synaptic terminals $[5,11,36]$, myelin fragments [37], and misfolded proteins [10]. 
The goal of this study was to examine MHC II pathway gene expression and glial activation measures in adult and aged, cognitively stratified animals to determine the relationship of these neuroinflammatory measures to cognitive decline. Despite the widely accepted concept of increased glial activation and MHC II induction with aging, quantitative assessments of hippocampal microglial activation (percentage of total microglial activated) and comprehensive assessment of MHC II gene expression have not been performed in behaviorally characterized adult and aged animals. Additionally, the distribution these neuroinflammatory measures across hippocampal subregions has not been examined. This work demonstrates for the first time that induction of the MHC II antigen processing and presentation pathway with aging occurs concomitantly with glial activation, and involves upregulation of complement and toll-like receptors as well as downstream inflammation response factors. Our findings also indicate that induction of hippocampal neuroinflammation, while a potential contributing factor to cognitive decline, does not in itself manifest in age-related impairment of spatial learning and memory.

\section{Methods}

\section{Animals}

Male Fischer $344 \times$ Brown Norway (F1) hybrid rats (see Table 1 for cohort information) were purchased from the Harlan Industries (Indianapolis, IN) National Institute on Aging colony as previously described [27] and quarantined/acclimatized for two weeks upon arrival. Rats were singly housed in laminar flow cages with free access to food (Purina Mills, Richmond, IN) and water and maintained on a 12-hour light/dark cycle with constant temperature and humidity in the OUHSC specific pathogen-free Barrier Facility. One week after completion of behavioral testing, rats were sacrificed by decapitation without anesthesia, and the hippocampi rapidly dissected for synaptosome preparation (set 1) or hippocampal subregion dissection (set 2). Alternatively, rats were perfusion-fixed, and their brains extracted for immunohistochemistry (set 3 ). At sacrifice, animals were examined for exclusionary criteria (e.g., kidney disease, cardiac hypertrophy, peripheral tumors, pituitary tumors, cortical atrophy). The OUHSC animal facilities are fully accredited by the Association for Assessment and Accreditation of Laboratory Animal Care, and all animal procedures were approved by the Institutional Animal Care and Use Committee in compliance with the Public Health Service Policy on Humane Care and Use of Laboratory Animals and the National Research Council's Guide for the Care and Use of Laboratory Animals. The three independent animal cohorts used in this study are summarized in Table 1.

\section{Morris water maze testing}

Rats were acclimatized to the OUHSC Barrier Facility for two weeks prior to hippocampus-dependent spatial learning and memory assessment conducted as previously described $[27,38]$. Briefly, a water maze $(1.7 \mathrm{~m} \times 0.6 \mathrm{~m})$ was filled to a depth of $25 \mathrm{~cm}$ with water made opaque with non-toxic, water-based white food coloring, and a retractable $12 \mathrm{~cm}^{2}$ escape platform was fixed $2 \mathrm{~cm}$ beneath the water's surface. A curtain with fixed-position visual cues, serving as reference cues for the location of the escape platform, surrounded the maze pool. A centermounted camera provided visual input to an automated tracking system (Noldus Ethovision XT, Wageningen, Netherlands) for evaluation of maze performance. Task acquisition was conducted over eight days, in two-day blocks consisting of five $60 \mathrm{~s}$ trials each. The submerged escape platform position was fixed throughout acquisition. Path length to find the platform was the dependent measure, with shorter path lengths indicating better performance. After completion of each acquisition block (i.e., on

Table 1 Animal cohort information

\begin{tabular}{|c|c|c|c|c|c|}
\hline Cohort & $\begin{array}{c}\text { Age } \\
\text { (months) }\end{array}$ & Group & n & Sample Type & Analyses Performed \\
\hline \multirow[t]{3}{*}{$1^{*}$} & 12 & Adult & 5 & & \\
\hline & 28 & Aged Intact & 8 & $\begin{array}{c}\text { synaptosomes } \\
\text { (whole hippocampus) }\end{array}$ & Morris water maze, transcriptomic analysis, qPCR \\
\hline & 28 & Aged Impaired & 7 & & \\
\hline \multirow[t]{3}{*}{2} & 12 & Adult & 7 & & \\
\hline & 26 & Aged Intact & 7 & $\begin{array}{l}\text { Hippocampal subregions } \\
\text { (CA1, CA3, DG) }\end{array}$ & Morris water maze, qPCR, immunoblotting \\
\hline & 26 & Aged Impaired & 10 & & \\
\hline \multirow[t]{3}{*}{$3^{*}$} & 13 & Adult & 3 & & \\
\hline & 26 & Aged Intact & 3 & Perfusion-fixed sagittal brain sections & Morris water maze, immunohistochemistry \\
\hline & 26 & Aged Impaired & 3 & & \\
\hline
\end{tabular}

* Described in reference 27 
days 2, 4, 6 and 8), a 30 s probe trial was performed with the escape platform removed. Rats were placed into the maze and the mean proximity to the platform location, duration in the annulus-40 (the area $40 \mathrm{~cm}$ around the platform location), cumulative distance, and mean swim velocity were recorded. To avoid extinguishing memory of the platform location, the platform was then replaced and rats were given an additional $60 \mathrm{~s}$ to locate it using the surrounding cues. Two days following conclusion of water maze testing, visual performance was assessed over four consecutive swim trials with the escape platform visible to ensure that maze performance was not affected by visual deficits.

Probe trial data were used to segregate aged animals into cognitively intact and impaired groups relative to the performance of adult rats, allowing retrospective analysis of acquisition phase data by group. As previously described [27], mean proximity to the escape platform location was used as the primary measure of cognitive performance on probe trials based on demonstration of its superior sensitivity compared to alternative measures [39]. The number of cumulative platform location crossings was used as a secondary measure of cognitive performance [40]. For descriptive purposes mean probe trial proximity-to-platform values of retrospectively stratified groups were assessed by one-way ANOVA with Student Newman Keuls (SNK) post hoc testing to confirm that the performance of the aged, cognitively impaired group was indeed inferior to the adult and aged, cognitively intact groups. To ascertain successful learning of the task by probe performance-stratified groups, acquisition data were statistically analyzed across blocks by one-way repeated measures ANOVA with Holm-Sidak post hoc testing. Significance of group differences for individual acquisition blocks and probe trials was assessed by one-way ANOVA with Student Newman Keuls post hoc testing.

\section{Synaptosome isolation}

Hippocampal synaptosomes were prepared as previously described [12,27]. Briefly, hippocampi were rapidly dissected into ice-cold HEPES-buffered sucrose $(320 \mathrm{mM}$ sucrose, $4 \mathrm{mM}$ HEPES, $1 \mathrm{mM}, \mathrm{Na}_{3} \mathrm{VO}_{4}, \mathrm{pH}$ 7.4) and incubated on ice for $30 \mathrm{~min}$ with buffer replaced twice at 10 minute intervals. Hippocampi were homogenized in $8 \mathrm{~mL}$ buffered sucrose with a mechanically-driven dounce and nuclear, cytoskeletal, and synaptosomal fractions were separated by differential centrifugation. Synaptosome samples were then resuspended in Tri-Reagent for subsequent RNA extraction.

\section{Hippocampal subregion dissection}

For dissection of hippocampal subregions of interest (CA1, CA3, DG), left and right hippocampi were individually hemisected and the dorsomedial portion was further dissected into four blocks perpendicular to the longitudinal axis. From these blocks, the CA3 was dissected by cutting along the edge of the DG and the CA1 and DG were dissected by cutting along the hippocampal fissure as described previously [41].

\section{Perfusion fixation and embedding}

Rats used for immunohistochemical assessment were anesthetized with ketamine/xylazine and transcardially perfused with $6 \mathrm{U} / \mathrm{mL}$ heparin (sodium salt) in PBS followed by phosphate-buffered $4 \%$ paraformaldehyde $(\mathrm{pH}$ 7.4). Brains were extracted and hemisected sagittally, immersion-fixed in $4 \%$ paraformaldehyde ( $\mathrm{pH} 7.4$ ) overnight at $4^{\circ} \mathrm{C}$, rinsed twice in PBS, and impregnated with $30 \%$ sucrose as previously described [27]. Tissue samples were embedded in Tissue-Tek optimal cutting temperature compound (Sakura Finetek, Torrance, CA, USA), frozen in isopentane on dry ice, and stored at $-80^{\circ} \mathrm{C}$.

\section{RNA isolation}

Hippocampal synaptosome and dissected subregion samples were homogenized in $300 \mu \mathrm{L}$ TriReagent (Molecular Research Center, Cincinnati, OH) by bead mill (Retsch TissueLyzer II, Qiagen, Valencia CA, USA) as previously described [27]. RNA was isolated from synaptosomal homogenates by addition of 10\% BCP and standard phase separation, followed by overnight isopropanol precipitation at $-20^{\circ} \mathrm{C}$. RNA was purified using the Qiagen RNeasy Mini kit (Qiagen), and quality and quantity were assessed by microfluidics chip (Agilent 2100 Expert Bioanalyzer Nano Chip, Agilent, Palo Alto, CA) and spectrometry (NanoDrop ND1000; Thermo Scientific, Wilmington, DE), respectively, with RNA integrity numbers $>8$ used as exclusion criteria.

\section{Microarray analysis}

Transcriptomic analysis of hippocampal synaptosomes derived from adult, aged intact, and aged impaired rats ( $\mathrm{n}=5-7$ /group) was performed using Illumina RatRef-12 microarrays (Illumina, San Diego, CA) according to standard methods and as previously described $[42,43]$. Briefly, first-strand cDNA was synthesized from $500 \mathrm{ng}$ input RNA by two-hour incubation at $42^{\circ} \mathrm{C}$ with T7 Oligo(dT) primer, $10 \times$ First Strand buffer, dNTPs, RNase inhibitor, and ArrayScript. Second-strand cDNA was synthesized from first-strand cDNA by two hour incubation at $16^{\circ} \mathrm{C}$ with $10 \times$ Second Strand buffer, dNTPs, DNA polymerase, and $\mathrm{RNase} H$, purified using the Illumina TotalPrep kit (Ambion, Foster City, CA) according to the manufacturer's protocols and eluted in $19 \mu \mathrm{L} 55^{\circ} \mathrm{C}$ nuclease-free water. cRNA was synthesized from second-strand cDNA using the MEGAscript kit (Ambion), and labelled by incubation for 14 hours at $37^{\circ} \mathrm{C}$ with T7 $10 \times$ Reaction Buffer, T7 Enzyme mix, and Biotin-NTP mix. Following 
purification with the Illumina TotalPrep RNA Amplification kit (Ambion) according to manufacturer's instructions, cRNA yields were quantitated using a NanoDrop ND1000 spectrometer. Biotinylated cRNA (750 ng) was hybridized to RatRef-12 BeadChips by incubating for 20 hours at $58^{\circ} \mathrm{C}$ at a rocker speed of 5 . After incubation, BeadChips were washed and streptavidin-Cy3 stained, dried by centrifugation at $275 \times \mathrm{g}$ for $4 \mathrm{~min}$ and scanned and digitized using a Bead Station Bead Array Reader.

Arrays were quality control checked, and initial data analysis using average normalization with background subtraction was performed in GenomeStudio software (Illumina). The full microarray dataset has been deposited in the Gene Expression Omnibus, accession\# (GSE29511). Using detection p-values generated by GenomeStudio, probes were filtered for only those with present or marginal calls in $100 \%$ of the samples in at least one of the three experimental groups. This ensured that transcripts not reliably detected in the experiment were excluded from statistical analysis, and that genes potentially expressed in only one experimental animal group (i.e., in adult, aged intact or aged impaired rats only) were retained. Statistically significant differential gene expression was determined using a combination of pair-wise absolute value fold-change cutoff of 1.2 and oneway ANOVA with Student Newman Keuls post hoc testing $\mathrm{p}<0.05$ [43].

\section{Bioinformatic analysis and visualization}

Array data were imported into Ingenuity Pathway Analysis software (Ingenuity Systems, Redwood City, CA) for determination of significantly regulated pathways/ networks (Fisher's Exact Test, $\mathrm{p}<0.001$ ) represented by genes differentially expressed between groups. The distribution of gene expression for the regulated pathway of interest was visualized by a heatmap generated in GeneSpring GX11 (Agilent) with hierarchical clustering by individual samples and genes using average distance and complete linkage. Gene expression levels represented on the heatmap were log-scaled to the adult mean expression per gene, with green $<1.0$, black $=1.0$, and red $>1.0$, with color hue indicative of degree of down- or up-regulation.

\section{RT-qPCR}

Confirmation of gene expression levels was performed as previously described using whole-hippocampus synaptosomes ( $\mathrm{n}=5-8 /$ group $)$ with assessments expanded to individual hippocampal subregions $(\mathrm{n}=7$ 10/group). cDNA was synthesized from purified RNA with the ABI High-capacity cDNA Reverse Transcription kit (Applied Biosystems, Foster City, CA). For each sample, $1 \mu \mathrm{g}$ RNA was reacted with random primers, dNTPs, and MultiScribe Reverse Transcriptase enzyme using a GeneAmp PCR 9700 System (Applied Biosystems), as previously described $[27,43,44]$. qPCR analysis of targets of interest was performed using standard laboratory methods and TaqMan Assay-On-Demand (Applied Biosystems, Foster City, CA, USA) gene-specific primers/probe assays (Table 2) and a $7900 \mathrm{HT}$ Sequence Detection System (Applied Biosystems) $[27,43,44]$. Relative gene expression was calculated with SDS 2.2.2 software using the $2^{-\Delta \Delta C t}$ analysis method with $\beta$-actin as an endogenous control. Statistical analysis of age-related (i.e., adult vs. aged) gene expression changes in microarray-confirmation qPCR experiments was performed by two-tailed t-testing with BenjaminiHochberg multiple testing correction (BHMTC). To assess the potential regulation of mRNA expression with cognitive status (adult, aged cognitively intact, and aged cognitively impaired), qPCR data were analyzed by oneway ANOVA with BHMTC, followed by SNK post hoc testing of pair-wise comparisons. Potential relationships between gene expression and behavioral performance (mean proximity to platform) were assessed by Pearson product moment correlation analyses with BHMTC.

\section{Protein Extraction}

Soluble protein was isolated by homogenizing samples in a detergent-based protein lysis buffer containing protease and phosphatase inhibitors $(100 \mathrm{mM} \mathrm{NaCl}, 20$ mM HEPES, $1 \mathrm{mM}$ EDTA, $1 \mathrm{mM}$ dithiothreitol, 1.0\% Tween20, $1 \mathrm{mM} \mathrm{Na} \mathrm{VO}_{4}, 1$ Complete Mini EDTA-Free Protease Inhibitor Cocktail Tablet (Roche Applied Science, Indianapolis, IN) for every $10 \mathrm{~mL}$ lysis buffer) using a bead mill. Homogenates were incubated for 15 min at $4^{\circ} \mathrm{C}$ with gentle rocking, insoluble protein was pelleted by centrifugation $\left(12 \mathrm{~min}, 10,000 \times \mathrm{g}, 4^{\circ} \mathrm{C}\right)$, and the soluble protein-containing supernatant was collected. Protein yields were determined by bicinchoninic acid quantitation (Pierce, Rockford, IL) in technical triplicates, and samples were adjusted to a concentration of $4 \mu \mathrm{g} / \mu \mathrm{L}$ in protein lysis buffer and LDS sample buffer (Invitrogen, Carlsbad, CA).

\section{Immunoblotting}

Immunoblot analysis of GFAP and Iba1 expression was conducted using standard laboratory methods [12,27]. $10 \mu \mathrm{g}$ of each prepared protein sample was denatured by heating to $95^{\circ} \mathrm{C}$ for $5 \mathrm{~min}$ prior to separation by SDSPAGE using Criterion Tris- $\mathrm{HCl}$ precast gels (4-20\% acrylamide gradient, $1 \mathrm{~mm}$ thick, 26 wells; BioRad, Hercules, CA, USA). To ensure equal protein content between samples, one gel containing all study samples was fixed with $10 \%$ ethanol $/ 1 \%$ citric acid, stained with Deep Purple total protein stain according to manufacturer's instructions (GE LifeSciences), and quantitated by wholelane digital densitometry (ImageQuant TL, Molecular 
Table 2 Primer/probe information

\begin{tabular}{|c|c|c|c|}
\hline Gene Symbol & Gene ID & Gene Name & TaqMan AOD \# \\
\hline $\mathrm{C} 1 \mathrm{~s}$ & 192262 & complement component 1 , subcomponent s & Rn00594278_m1 \\
\hline $\mathrm{C} 3$ & 24232 & complement component 3 & Rn00566466_m1 \\
\hline $\mathrm{C} 4 \mathrm{a}$ & 24233 & complement component $4 a$ & Rn00709527_m1 \\
\hline Ccr5 & 117029 & chemokine (C-C motif) receptor 5 & Rn00588629_m1 \\
\hline $\mathrm{Cd} 74$ & 25599 & CD74 molecule, major histocompatibility complex, class II invariant chain & Rn00565062_m1 \\
\hline$C p$ & 24268 & ceruloplasmin & Rn00561049_m1 \\
\hline Ctse & 25424 & cathepsin E & Rn00564036_m1 \\
\hline Erbb3 & 29496 & v-erb-b2 erythroblastic leukemia viral oncogene homolog 3 & Rn00568107_m1 \\
\hline Fcgr2a & 116591 & Fc fragment of IgG, low affinity Ila, receptor (CD32) & Rn00821543_g1 \\
\hline Fcgr2b & 289211 & Fc fragment of lgG, low affinity IIb, receptor (CD32) & Rn00598391_m1 \\
\hline Hla-dmb & 3109 & major histocompatibility complex, class II, DM beta & Rn01429041_m1 \\
\hline Hla-dra & 294269 & major histocompatibility complex, class II, DR alpha & Rn01427980_m1 \\
\hline Hla-drb1 & 294270 & major histocompatibility complex, class II, DR beta 1 & Rn01429350_m1 \\
\hline Hsbp1 & 286899 & heat shock factor binding protein 1 & Rn00583001_g1 \\
\hline Icam1 & 25464 & intercellular adhesion molecule 1 & Rn00564227_m1 \\
\hline Lgals3 & 83781 & lectin, galactoside-binding, soluble, 3 & Rn00582910_m1 \\
\hline S100a6 & 85247 & S100 calcium binding protein A6 & Rn00821474_g1 \\
\hline Serping1 & 295703 & serpin peptidase inhibitor, clade G (C1 inhibitor), member 1 & Rn01485600_m1 \\
\hline Tlr2 & 310553 & toll-like receptor 2 & Rn02133647_s1 \\
\hline Tlr4 & 29260 & toll-like receptor 4 & Rn00569848_m1 \\
\hline T/r7 & 317468 & toll-like receptor 7 & Rn01771083_s1 \\
\hline
\end{tabular}

Dynamics, Synnyvale, CA) as previously described [12] For immunoblotting, SDS-PAGE separated proteins were transferred to PVDF membranes (HyBond, GE Healthcare) and blocked with 5\% nonfat milk in PBS with 1.0\% Tween-20 (PBST) prior to overnight incubation with primary antibodies to GFAP (1:1000) and Iba1 (1:2000) (Table 3) in blocking solution at $4^{\circ} \mathrm{C}$ with gentle rocking. Membranes were washed with PBST, incubated with secondary antibody (horseradish peroxidase-conugated donkey-anti-rabbit IgG, 1:2500), and developed with enhanced chemiluminescence substrate (GE Healthcare). Immunoreactive bands were imaged on film, digitized at a resolution of $800 \mathrm{dpi}$, and quantitated using automated digital densitometry software (ImageQuant TL). Immunoblot data were normalized to corresponding wholelane densitometric volumes of the total protein stained gel. Pairwise comparisons (i.e., adult vs. aged groups) were assessed by two-tailed t-tests.

\section{Immunohistochemistry}

Three rats from each group (adult, aged intact, aged impaired) were included in this analysis. Tissues were cryosectioned $(12 \mu \mathrm{m})$ in the sagittal plane (HN 505E, Microm International, Walldorf, Germany) at $-19^{\circ} \mathrm{C}$, and sections were collected on glass slides (FisherBrand SuperFrost Plus, Fisher Scientific, Pittsburg, PA). As previously described [27] sections were postfixed with $2.0 \%$ paraformaldehyde, $\mathrm{pH}$ 7.4, and blocked with $10 \%$ donkey serum (Jackson ImmunoResearch, WestGrove, PA) in $0.1 \%$ Triton X-100 in PBS. Sections were incubated overnight at $4^{\circ} \mathrm{C}$ in blocking buffer with the addition of either antibodies to Iba1 (microglia-specific marker) and CD74 (MHC II invariant chain; activation-specific microglial marker) to visualize total and activated microglia, or to GFAP to visualize astrocytes (Table 3). Negative control slides with primary antibody were included to identify potential non-specific, background immunofluorescence of tissue and secondary antibodies. Sections were washed with $0.1 \%$ Triton X-100 in PBS, incubated with affinitypurified, species-appropriate fluorescence-conjugated secondary antibodies (donkey-anti-rabbit DyLight 649, 1:200, or donkey-anti-mouse DyLight 488, 1:200; Jackson ImmunoResearch, West Grove, PA) diluted in blocking solution, and counterstained with Hoechst 33258 (5 $\mu \mathrm{g} /$ $\mathrm{mL}$, Invitrogen, Carlsbad, CA). After washing, slides were coverslipped with Aqua Poly/mount (Polysciences, Warrington, PA, USA) and imaged by confocal microscopy.

Images were acquired using a confocal laser scanning microscope (Leica TCS SP2 AOBS, Exton, PA) equipped with UV-diode (Hoechst, $405 \mathrm{~nm}$ ), argon (488 nm), and helium-neon (546 nm and $633 \mathrm{~nm}$ ) lasers. Subregions were imaged using a $20 \times$ objective, as $8 \mu \mathrm{m}$ series of 24 optical sections $(0.3 \mu \mathrm{m}$ step size, $1024 \times 1024$ pixel resolution) and presented as average projections of $\mathrm{z}$-stacks. 
Table 3 Antibody information

\begin{tabular}{|c|c|c|c|c|c|}
\hline Target & Supplier & Catalog \# & Host & Use & Method* \\
\hline Glial fibrillary acidic protein (GFAP) & Abcam & 7620 & rabbit & primary & $\mathrm{IB} / \mathrm{IHC}$ \\
\hline lonized calcium binding adaptor molecule 1 (Iba1) & Wako Pure Chemical Industries & 1620001 & rabbit & primary & IB \\
\hline Ionized calcium binding adaptor molecule 1 (Iba1) & Wako Pure Chemical Industries & 1919741 & rabbit & primary & $\mathrm{IHC}$ \\
\hline MHC2 invariant chain (CD74; Ox6) & Abcam & 23990 & mouse & primary & $\mathrm{IHC}$ \\
\hline $\begin{array}{c}\text { Rabbit lgG } \\
\text { (HRP-conjugated) }\end{array}$ & GE Healthcare & NA934V & donkey & secondary & IB \\
\hline Rabbit $\left[\mathrm{F}\left(a b^{\prime}\right)_{2}\right]$ & Jackson ImmunoResearch & 711496152 & donkey & secondary & $\mathrm{IHC}$ \\
\hline Mouse $\left[F\left(a b^{\prime}\right)_{2}\right]$ & Jackson ImmunoResearch & 715486150 & goat & secondary & $\mathrm{IHC}$ \\
\hline
\end{tabular}

* IB: immunoblotting; IHC: immunohistochemistry

Detailed images were obtained using a $63 \times$ objective $4 \times$ digital zoom with $2 \times 2$ line and frame averaging. Noise reduction and background subtraction were performed using Adobe Photoshop CS4 software, with equal adjustments applied to all images of the same antibody (Adobe Systems, San Jose, CA, USA). All images were assessed to ensure that there was no signal saturation in any channel.

\section{Quantitation of astrocyte and microglia populations}

Hippocampal subregions of interest (CA1, CA3, DG) were imaged as $8 \mu \mathrm{m}$ stacks for quantitation in three tissue sections per animal per group (adult, aged cognitively intact, aged cognitively impaired, $n=3$ /group. To identify potential proliferation of astrocytes, the number of $\mathrm{GFAP}^{+}$cells per subregion of interest was quantified using ImageJ software with the cell counter plug-in (NIH, Bethesda, MD). Quantitation of total microglia ( $\mathrm{Iba1}^{+}, \mathrm{CD} 74^{-}$, red signal), mildly activated microglia ( $\mathrm{Iba}^{+}$, weakly $\mathrm{CD} 74^{+}$, orange signal), and moderately activated microglia (Iba ${ }^{+}$, highly $\mathrm{CD}^{+} 4^{+}$, yellow signal) was performed using the cell counter plug-in for ImageJ. For each subregion and tissue section, the number of mildly- and moderately-activated microglia was calculated as a percentage of total microglia present in that subregion. For all quantitation experiments, the three sections per animal were treated as technical triplicates and, for each subregion, were averaged to yield either 1$)$ the density of astrocytes per subregion (GFAP ${ }^{+}$ cells per $\left.100 \mu \mathrm{m}^{2}\right)$, 2) the density of microglia per subregion ( $\mathrm{Iba}^{+}$cells per $100 \mu \mathrm{m}^{2}$ ), or 3 ) the percentage of mildly- and moderately-activated microglia. These data were analyzed for statistical significance by one-way ANOVA with SNK post hoc testing.

\section{Results}

Behavioral stratification of adult and aged rats by Morris water maze performance

Hippocampus-dependent cognitive performance of Fischer $344 \times$ Brown Norway hybrid (F1) male rats was assessed by Morris water maze testing, and aged animals were assigned to cognitively intact or cognitively impaired groups based on mean proximity to the escape platform during probe trials as previously described [25,27]. In all three animal cohorts used in this study, aged rats performing within the range of the adult group were classified as cognitive intact, while those with mean proximity values greater than two standard deviations above the adult group mean were classified as cognitively impaired (Figure 1). The mean probe trial performance of both adult and aged cognitively intact groups was superior to the aged impaired group, as verified by one-way ANOVA with SNK post hoc testing ( $\mathrm{p}<0.001)$. Retrospective analysis of acquisition phase performance demonstrated that all groups successfully learned the task, as demonstrated by decreasing path length across acquisition blocks (repeated measures ANOVA, p < 0.001). Characterization of these animals has been described, in part, elsewhere [27] and is summarized in Table 1 and Figure 1.

\section{Age-related upregulation of the MHC II antigen presentation pathway}

Transcriptomic data obtained by microarray analysis of hippocampal synaptosomes derived from adult, aged intact, and aged impaired rats (cohort 1) were subjected to bioinformatic analysis to identify ontologies and pathways over-represented in the differentially-expressed genes. Gene Ontology (GO) analysis identified the antigen processing and presentation of exogenous antigen via MHC II (GO:019886) as over-represented among changes (Fisher's Exact Test, $\mathrm{p}<0.002$ ). Pathway analysis (Ingenuity) also identified the MHC II antigen presentation pathway as significantly upregulated with aging (Fisher's Exact test, $\mathrm{p}<0.0001$ ). Genes encoding $21 \mathrm{com-}$ ponents of the MHC II machinery, antigen recognition receptors, and downstream inflammatory signaling factors (Figure 2) were significantly increased in both aged intact and aged impaired rats compared to adults. Differences in expression of these genes were not detected between aged intact and aged impaired groups. The full transcriptomic dataset is publically available [Gene Expression Omnibus, accession \# (GSE29511)]. 


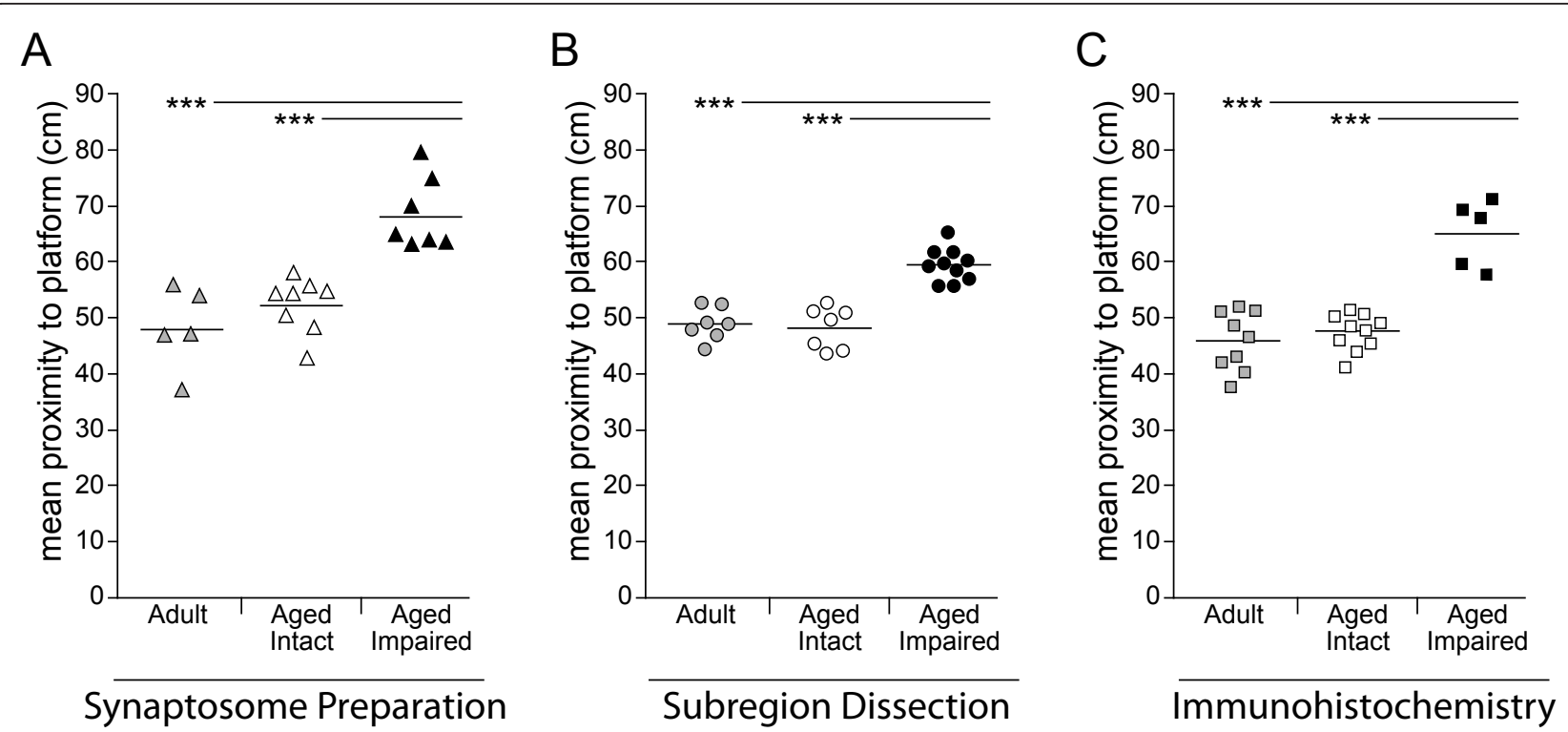

Figure 1 Stratification of aged rats by cognitive performance. Three independent cohorts of adult (12-13 months) and aged (26-28 months) male Fischer $\times$ Brown Norway hybrid (F1) rats were assessed for hippocampus-dependent spatial learning and memory using the Morris water maze. Using mean proximity to the escape platform location as the dependent variable, aged rats performing within the range of adults were classified as cognitively intact, while those with poorer performance were classified as cognitively impaired. Based on this stratification, the performance of both adult and aged intact rats was significantly superior to aged impaired rats in (A) set 1: utilized for preparation of wholehippocampus synaptosomal fractions used in transcriptomic profiling and mRNA quantitation, (B) set 2: utilized for dissection of CA1, CA3 and DG used in mRNA and protein quantitation, and (C) set 3: perfusion-fixed for immunohistochemical assessments. Points represent individual animals and horizontal bars indicate group means; ${ }^{* *} p<0.001$, ANOVA SNK post hoc test. See Table 1 for cohort information. Behavioral data for cohorts 1 and 3 are adapted from reference 27.

\section{Differential MHC II and related gene expression with aging occurs throughout the hippocampus}

To confirm the transcriptomic finding that the MHC II immune pathway is upregulated with aging in hippocampal synaptosome samples and expand quantitation to individual hippocampal subregions, qPCR analysis of 21 MHC II-associated genes differentially expressed in the microarray analysis was performed. This quantitative analysis was performed using the same synaptosomal fractions assessed by microarray profiling, as well as unfractionated CA1, CA3 and DG dissections derived from an independent, behaviorally characterized animal cohort. qPCR data was first examined for age-related changes (all aged vs. adult, t-test, BHMTC) to confirm the microarray findings. qPCR data were also compared to individual animal performance data for potential significant correlations to behavioral performance (Pearson correlation, BHMTC). Additionally, a three-group comparison with the aged group split into intact and impaired groups was performed to examine potential cognition specific-effects (ANOVA, with SNK pairwise comparisons, BHMTC). Statistical results are summarized in Table 4 , and group means ( \pm S.E.M.) are presented in Table 5. All 21 genes selected from the transcriptomic data for confirmation were significantly induced with aging in the synaptosomal samples. In subregion samples the age-related induction of gene expression was most evident in CA3 and CA1, with fewer genes significantly upregulated in the DG (Table 4). MHC II component genes were the most highly induced genes, with age-related increases in expression as high as 10fold. While direct statistical comparisons between subregions are not possible as these data were in collected independent qPCR experiments, the magnitude of changes was generally highest in synaptosomal samples, followed by CA3 and CA1. In no case did expression of these 21 age-regulated genes significantly correlate with cognitive performance. In only two instances were expression differences evident between aged impaired and aged intact groups (DG; Hla-dmb, C3) and these were of a small magnitude.

\section{Hippocampal expression of astrocytic and microglial markers is upregulated with aging}

Upregulation of MHC II-associated genes with aging suggests a heightened immune response [45] in the aged hippocampus. To determine whether increased expression of these genes is associated with age- or cognitive statusrelated increases in glial activation, and whether potential glial activation occurs throughout the hippocampus or in 


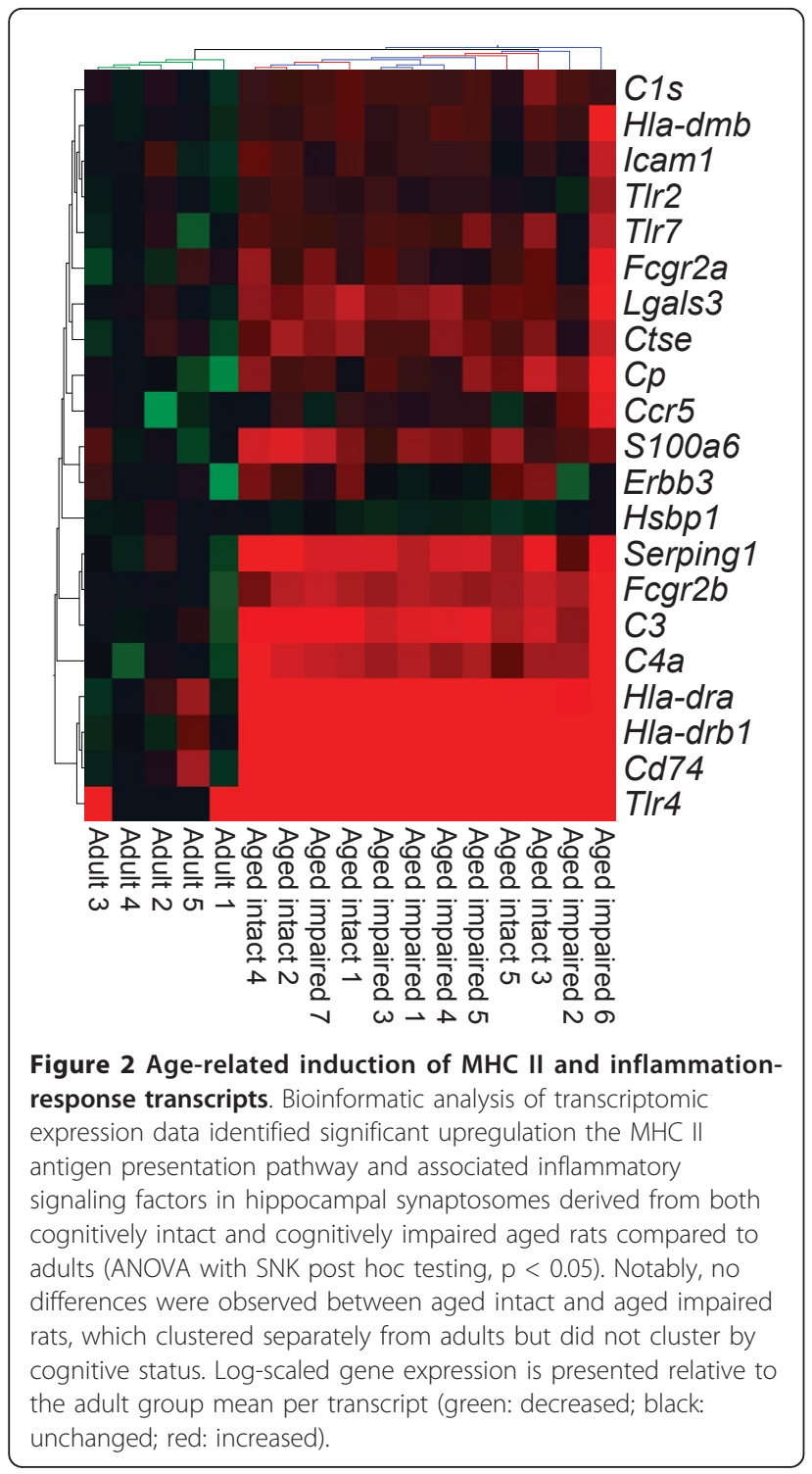

a circumscribed subregion, expression of astrocyte-specific (GFAP) and microglia-specific (Iba1) protein markers was assessed by immunoblotting in adult, aged cognitively intact, and aged cognitively impaired rats. In both aged intact and aged impaired rats, significant increases in GFAP expression ranging from $50 \%$ to $80 \%$, relative to adults, were detected in CA1 ( $p<0.001)$, CA3 ( $p<0.05)$ and DG ( $<$ 0.05) (ANOVA, SNK; Figure 3A). Likewise, Iba1 expression was significantly elevated by $\sim 30 \%$ in CA1 of aged intact $(\mathrm{p}<0.05)$ and aged impaired $(\mathrm{p}<0.001)$ rats compared to adults, and in CA3 of aged impaired rats compared to adults $(\sim 45 \%, \mathrm{p}<0.001)$ (ANOVA, SNK; Figure $3 \mathrm{~B}$ ). A similar trend was observed in the CA3 of aged intact rats, although it did not reach statistical significance. No changes in expression of Iba1 were detected in DG. Expression of GFAP and Iba1 was not different between aged intact and aged impaired rats in any subregion and did not correlate to individual animal MWM performance.

Immunohistochemical visualization of astrocyte activation To extend immunoblot data indicative of glial activation, immunohistochemical characterization of astrocytes was performed using adult, aged intact, and aged impaired rats. This approach enabled visualization of age-related changes in GFAP immunoreactivity as well as assessment of potential changes in localization of astrocytes associated with aging and cognitive impairment (Figure 4). GFAP-immunoreactive astrocytes were distributed throughout DG, CA1 and CA3, and were associated with both cell body and synaptic layers. Notable increases in the intensity of GFAP immunoreactivity within cells was evident in CA1 and CA3 of aged cognitively intact and aged cognitively impaired rats compared to adults, with the most dramatic age-related changes evident in DG. No subregion-specific qualitative differences in astrocyte immunoreactivity or distribution were evident between aged intact and aged impaired rats, suggesting that increased astrocyte activation is associated with advanced age but not further exacerbated with cognitive decline. Quantitation of $\mathrm{GFAP}^{+}$cells revealed no age- or cognitive decline-associated changes in astrocyte density (mean \pm S.E.M) in DG (astrocytes $/ 100 \mu \mathrm{m}^{2}$ : adult: $60 \pm 2.7$, aged intact: $58 \pm 1.1$, aged impaired: $61 \pm 1.8$ ), CA3 (astrocytes $/ 100 \mu \mathrm{m}^{2}$ : adult: $74 \pm 2.4$, aged intact: $76 \pm 3.2$, aged impaired: $72 \pm 1.2$ ), or CA1 (astrocytes $/ 100 \mu \mathrm{m}^{2}$ : adult: $56 \pm 1.3$, aged intact: $54 \pm 1.5$, aged impaired: $56 \pm 2.1$ ) These results suggest that the age-related increase in GFAP expression demonstrated by immunoblotting and immunohistochemistry reflects increased astrocyte activation rather than proliferation.

Morphological assessment also revealed an activated astrocytic phenotype associated with the aged hippocampus (Figure 5). In adult rats, astrocytes expressed low levels of GFAP, exhibited a stellate morphology with numerous thin, branched processes, and were spatially distinct. In both aged intact and aged impaired rats, cellular GFAP immunoreactivity was dramatically increased and astrocytes appeared hypertrophic. Consistent with mild reactive gliosis, GFAP-containing processes were visibly thicker and more highly ramified, and a degree of spatial overlap was evident.

\section{Quantitation of activated microglia}

Visualization of activated microglia was achieved by immunohistochemical co-detection of Iba1 (microgliaspecific marker) and CD74 (OX-6 antibody, MHC II invariant chain; activation-specific microglial marker) (Figure 6). Co-staining offers the benefit of determining the percentage of total microglia activated as opposed to measuring CD74 alone. Iba1-immunoreactive microglia 
Table 4 qPCR confirmation of age-related induction of MHC II pathway component genes

Gene All Aged vs. Adult (ratio, $p$-value t- Pearson Correlation to Morris Aged Intact vs. Adult (ratio, $p$-value Aged Impaired vs. Adult(ratio, $p$ - $\quad$ Aged Impaired vs.

test) water maze SNK)

SNK) value SNK

Aged Intact(ratio, p-value

SNK)

\begin{tabular}{|c|c|c|c|c|c|c|c|c|c|c|c|c|c|c|c|c|c|c|c|c|}
\hline & Syn & CA1 & CA3 & DG & Syn & CA1 & CA3 & DG & Syn & CA1 & CA3 & DG & Syn & CA1 & CA3 & DG & Syn & CA1 & CA3 & DG \\
\hline \multicolumn{21}{|c|}{$\begin{array}{l}\text { MHC II } \\
\text { Components }\end{array}$} \\
\hline $\mathrm{Cd} 74$ & $6.58^{\# \# \#}$ & $5.61^{\# \# \#}$ & $3.61^{\# \# \#}$ & $2.43^{\# \# \# \#}$ & - & - & - & - & $6.79^{* * *}$ & $5.66^{* * *}$ & $3.88^{* * *}$ & $2.43^{* * *}$ & $6.35^{* * *}$ & $5.58^{* * *}$ & $3.40^{* * *}$ & $2.49^{* * *}$ & - & - & - & - \\
\hline Ctse & $1.69^{\# \#}$ & $1.45^{\# \#}$ & $1.75^{\# \# \#}$ & $1.48^{\# \# \#}$ & - & - & - & - & $1.81^{*}$ & - & $1.73^{* * *}$ & $1.48^{*}$ & - & - & $1.77^{* * *}$ & $1.54^{* *}$ & - & - & - & - \\
\hline Hla-dmb & $1.64^{\# \# \#}$ & $1.37^{\# \# \#}$ & $1.37^{\# \# \#}$ & $1.26^{\# \#}$ & - & - & - & - & $1.57^{* *}$ & $1.33^{* *}$ & $1.39 * * *$ & - & $1.72^{* * *}$ & $1.40 * * *$ & $1.35^{* * *}$ & $1.33^{* *}$ & - & - & - & $1.16^{*}$ \\
\hline Hla-dra & $6.30^{\# \# \#}$ & $4.04^{\# \# \#}$ & $3.02^{\# \# \#}$ & - & - & - & - & - & $6.76^{* * *}$ & $4.18^{* * * *}$ & $3.25^{* * * *}$ & - & $5.75^{* *}$ & $3.95^{* * *}$ & $2.85^{* * *}$ & - & - & - & - & - \\
\hline Hla-drb1 & $10.50^{\# \# \#}$ & $7.13^{\# \# \#}$ & $4.39^{\# \# \#}$ & $2.91^{\#}$ & - & - & - & - & $10.70^{* * *}$ & $7.12^{* * *}$ & $4.77^{* * * *}$ & - & $10.26^{* * *}$ & $7.13^{* * *}$ & $4.12^{* * *}$ & $3.42^{* *}$ & - & - & - & - \\
\hline
\end{tabular}

Antigen

Recognition

\begin{tabular}{|c|c|c|c|c|c|c|c|c|c|c|c|c|c|c|c|c|c|c|c|c|}
\hline C1s & $1.84^{\#}$ & $1.21^{\#}$ & $1.56^{\# \# \#}$ & - & - & - & - & - & - & - & $1.59^{* *}$ & - & - & - & $1.53^{* * *}$ & - & - & - & - & - \\
\hline C3 & $3.47^{\# \# \#}$ & $2.00^{\# \# \#}$ & $1.96^{\# \# \#}$ & $1.69^{\# \# \#}$ & - & - & - & - & $3.40^{* *}$ & $2.07^{* * *}$ & $2.22^{* * *}$ & $1.52^{* * *}$ & $3.55^{* *}$ & $1.94^{* * *}$ & $1.78^{* * *}$ & $1.81^{* * *}$ & - & - & - & $1.19^{*}$ \\
\hline$C 4 a$ & $4.18^{\# \# \#}$ & $1.77^{\# \# \#}$ & $1.51^{\# \# \#}$ & - & - & - & - & - & $3.83^{* *}$ & $1.67^{* * *}$ & $1.58^{* * *}$ & - & $4.59^{* *}$ & $1.85^{* * *}$ & $1.47^{* * *}$ & - & - & - & - & - \\
\hline Serping 1 & $2.71^{\# \# \#}$ & $2.03^{\# \# \#}$ & $2.27^{\# \# \#}$ & $1.54^{\# \# \#}$ & - & - & - & - & $2.79^{* * *}$ & $2.18^{* * *}$ & $2.52^{* * *}$ & $1.49^{* *}$ & $2.63^{* * *}$ & $1.92^{* * *}$ & $2.09^{* * *}$ & $1.58^{* * *}$ & - & - & - & - \\
\hline T/r2 & $1.64^{\# \#}$ & - & 1.54\#\# & - & - & - & - & - & $1.55^{*}$ & - & $1.66^{*}$ & - & $1.73^{*}$ & - & $1.46^{*}$ & - & - & - & - & - \\
\hline T/r4 & $1.51^{\# \#}$ & $1.35^{\#}$ & $1.96^{\# \# \#}$ & - & - & - & - & - & $1.41^{*}$ & - & $2.00^{* * *}$ & - & $1.60^{*}$ & - & $1.93^{* * *}$ & - & - & - & - & - \\
\hline T/r7 & $1.69^{\# \#}$ & $1.34^{\# \#}$ & $1.73^{\# \# \#}$ & - & - & - & - & - & $1.65^{*}$ & $1.34^{*}$ & $1.74^{* * *}$ & - & $1.73^{*}$ & $1.35^{*}$ & $1.72^{* * *}$ & - & - & - & - & - \\
\hline
\end{tabular}

Immune Cell Activating

\begin{tabular}{|c|c|c|c|c|c|c|c|c|c|c|c|c|c|c|c|c|c|c|c|c|}
\hline Ccr5 & $1.96^{\#}$ & - & - & - & - & - & - & - & - & - & - & - & - & - & - & - & - & - & - & - \\
\hline Erbb3 & $1.28^{\# \# \#}$ & $1.34^{\# \# \#}$ & $1.20^{\#}$ & $1.40^{\#}$ & - & - & - & - & $1.26^{* *}$ & $1.43^{* * *}$ & - & - & $1.30^{* *}$ & $1.28^{* *}$ & - & $1.47^{* *}$ & - & - & - & - \\
\hline Fcgr2a & $1.45^{\#}$ & $1.19^{\#}$ & $1.30^{\# \# \#}$ & & - & - & - & - & - & - & $1.30^{* *}$ & - & - & - & $1.30^{* *}$ & - & - & - & - & - \\
\hline Fcgr2b & $1.96^{\# \#}$ & - & $1.61^{\# \# \#}$ & - & - & - & - & - & $2.08^{*}$ & - & $1.63^{* * *}$ & - & $1.82^{*}$ & - & $1.60^{* * *}$ & - & - & - & - & - \\
\hline \multicolumn{21}{|c|}{ Inflammation Response } \\
\hline$C p$ & $1.67^{\#}$ & - & $1.56^{\# \# \#}$ & - & - & - & - & - & $1.92^{*}$ & - & $1.64^{* * *}$ & - & - & - & $1.50^{* * *}$ & - & - & - & - & - \\
\hline Hsbpl & $2.87^{\# \# \#}$ & $1.68^{\# \# \#}$ & $2.09^{\# \# \#}$ & - & - & - & - & - & $3.13^{* *}$ & $1.65^{* *}$ & $2.25^{* * *}$ & - & $2.58^{* * * *}$ & $1.70^{* *}$ & $1.97^{* * *}$ & - & - & - & - & - \\
\hline Icam1 & $1.46^{\#}$ & $1.55^{\# \# \#}$ & $1.43^{\# \# \#}$ & - & - & - & - & - & - & $1.68^{* * *}$ & $1.64^{* * *}$ & - & - & $1.46^{* *}$ & $1.31^{* *}$ & - & - & - & - & - \\
\hline Lgals3 & $3.42^{\# \#}$ & $2.64^{\# \# \#}$ & $1.98^{\# \# \#}$ & $1.84^{\# \#}$ & - & - & - & - & $3.68^{* * *}$ & $2.62^{* * *}$ & $2.18^{* * *}$ & $1.63^{*}$ & $3.03^{* * *}$ & $2.66^{* * *}$ & $1.84^{* * *}$ & $2.00^{* *}$ & - & - & - & - \\
\hline S100a6 & $1.52^{\#}$ & $2.03^{\# \# \#}$ & $2.21^{\# \# \#}$ & - & - & - & - & - & - & $2.00^{* * * *}$ & $2.48^{* * *}$ & - & - & $2.06^{* * *}$ & $2.02^{* * *}$ & - & - & - & - & - \\
\hline
\end{tabular}

GPCR confirmation of transcriptomic findings was performed in hippocampal synaptosomes and expanded to include hippocampal subregion dissections. Age-based comparisons (aged intact and aged impaired versus adult) were statistically analyzed by two-tailed $\mathrm{t}$-test with BHMTC $\left({ }^{\#} \mathrm{p}<0.05\right.$; ${ }^{\# \#} \mathrm{p}<0.01$; $\left.{ }^{\# \#} \mathrm{p}<0.001\right)$. Three-group data (adult, aged intact, aged impaired) were statistically analyzed by one-way ANOVA with BHMTC, and pairwise comparisons were evaluated by SNK post hoc testing to identify potential regulation of gene expression with cognitive decline ${ }^{*} \mathrm{p}<0.05$; ${ }^{* *} \mathrm{p}<0.01$; $\left.{ }^{* * *} \mathrm{p}<0.001\right)$. Correlation of gene expression with Morris water maze performance was assessed by Pearson product moment analysis with BHMTC, which demonstrated no significant association of MHC II pathway gene expression and cognitive impairment. Data are presented as ratios of group means. Individual group gene expression data is presented in Table 5. 
Table 5 Gene expression levels of age and cognitive status groups, presented as group mean (\% of adult mean) \pm SEM

\begin{tabular}{|c|c|c|c|c|c|c|c|c|c|c|c|c|c|c|c|c|}
\hline & \multicolumn{4}{|c|}{ CA1 } & \multicolumn{4}{|c|}{ CA3 } & \multicolumn{4}{|c|}{ DG } & \multicolumn{4}{|c|}{$\begin{array}{l}\text { synaptosomes (whole- } \\
\text { hippocampus) }\end{array}$} \\
\hline & & & Aged & Aged & & & Aged & Aged & & & Aged & Aged & & & Aged & Aged \\
\hline Gene & Adult & Aged & Intact & Impaired & Adult & Aged & Intact & Impaired & Adult & Aged & Intact & Impaired & Adult & Aged & Intact & Impaired \\
\hline Cls & $\begin{array}{l}100 \pm \\
2.8\end{array}$ & $\begin{array}{l}121 \pm \\
6.1\end{array}$ & $\begin{array}{l}125 \pm \\
11.7\end{array}$ & $\begin{array}{l}118 \pm \\
6.6\end{array}$ & $\begin{array}{l}100 \pm \\
7.8\end{array}$ & $\begin{array}{l}156 \pm \\
7.6\end{array}$ & $\begin{array}{l}159 \pm \\
13.4\end{array}$ & $\begin{array}{l}153 \pm \\
9.3\end{array}$ & & $\begin{array}{l}122 \pm \\
4.8\end{array}$ & $\begin{array}{l}117 \pm \\
5.7\end{array}$ & $\begin{array}{l}125 \pm \\
6.9\end{array}$ & $\begin{array}{l}100 \pm \\
21.7\end{array}$ & & $\begin{array}{l}182 \pm \\
28.6\end{array}$ & $\begin{array}{l}186 \pm \\
35.3\end{array}$ \\
\hline C3 & $\begin{array}{l}100 \pm \\
6.6\end{array}$ & & $\begin{array}{l}207 \pm \\
16.4\end{array}$ & $\begin{array}{l}194 \pm \\
15.0\end{array}$ & $\begin{array}{l}100 \pm \\
7.9\end{array}$ & $\begin{array}{l}196 \pm \\
10.8\end{array}$ & $\begin{array}{l}222 \pm \\
17.8\end{array}$ & $\begin{array}{l}178 \pm \\
10.7\end{array}$ & & $\begin{array}{l}169 \pm \\
7.2\end{array}$ & $\begin{array}{l}152 \pm \\
10.2\end{array}$ & $\begin{array}{l}181 \pm \\
8.3\end{array}$ & $\begin{array}{l}100 \pm \\
23.2\end{array}$ & $\begin{array}{l}347 \pm \\
35.7\end{array}$ & $\begin{array}{l}340 \pm \\
27.6\end{array}$ & $\begin{array}{l}355 \pm \\
74.4\end{array}$ \\
\hline Serping 1 & $\begin{array}{l}100 \pm \\
7.4\end{array}$ & $3.03 \pm$ & $\begin{array}{l}218 \pm \\
14.6\end{array}$ & $\begin{array}{l}192 \pm \\
20.2\end{array}$ & $\begin{array}{l}100 \pm \\
7.3\end{array}$ & $\begin{array}{l}227 \pm \\
11.5\end{array}$ & $\begin{array}{l}252 \pm \\
17.4\end{array}$ & $\begin{array}{l}209 \pm \\
13.1\end{array}$ & $\begin{array}{l}100 \pm \\
4.8\end{array}$ & $\begin{array}{l}154 \pm \\
6.3\end{array}$ & $\begin{array}{l}149 \pm \\
9.4\end{array}$ & $\begin{array}{l}158 \pm \\
8.7\end{array}$ & $\begin{array}{l}100 \pm \\
6.9\end{array}$ & $\begin{array}{l}271 \pm \\
12.4\end{array}$ & $\begin{array}{l}279 \pm \\
19.9\end{array}$ & $\begin{array}{l}263 \pm \\
15.5\end{array}$ \\
\hline$C d 74$ & $\begin{array}{l}100 \pm \\
7.7\end{array}$ & $\begin{array}{l}561 \pm \\
33.3\end{array}$ & $\begin{array}{l}566 \pm \\
44.5\end{array}$ & $\begin{array}{l}558 \pm \\
47.9\end{array}$ & $\begin{array}{l}100 \pm \\
10.9\end{array}$ & $\begin{array}{l}361 \pm \\
20.5\end{array}$ & $\begin{array}{l}388 \pm \\
37.6\end{array}$ & $\begin{array}{l}340 \pm \\
21.2\end{array}$ & $\begin{array}{l}100 \pm \\
7.7\end{array}$ & $\begin{array}{l}243 \pm \\
17.2\end{array}$ & $\begin{array}{l}233 \pm \\
36.7\end{array}$ & $\begin{array}{l}249 \pm \\
18.2\end{array}$ & $\begin{array}{l}100 \pm \\
28.8\end{array}$ & $\begin{array}{l}658 \pm \\
48.9\end{array}$ & $\begin{array}{l}679 \pm \\
46.7\end{array}$ & $\begin{array}{l}635 \pm \\
95.8\end{array}$ \\
\hline$C 4 a$ & $\begin{array}{l}100 \pm \\
7.1 \\
\end{array}$ & $\begin{array}{l}177 \pm \\
7.0\end{array}$ & $\begin{array}{l}167 \pm \\
11.1\end{array}$ & $\begin{array}{l}185 \pm \\
8.6\end{array}$ & $\begin{array}{l}100 \pm \\
4.8\end{array}$ & $\begin{array}{l}151 \pm \\
4.6\end{array}$ & $\begin{array}{l}158 \pm \\
6.2\end{array}$ & $\begin{array}{l}147 \pm \\
6.2\end{array}$ & $\begin{array}{l}100 \pm \\
9.7\end{array}$ & $\begin{array}{l}135 \pm \\
10.3\end{array}$ & $\begin{array}{l}117 \pm \\
15.2\end{array}$ & $\begin{array}{l}147 \pm \\
13.0\end{array}$ & $\begin{array}{l}100 \pm \\
17.7\end{array}$ & & $\begin{array}{l}383 \pm \\
31.6\end{array}$ & $\begin{array}{l}459 \pm \\
88.3\end{array}$ \\
\hline Ccr5 & $\begin{array}{l}100 \pm \\
5.2\end{array}$ & $\begin{array}{l}108 \pm \\
5.1\end{array}$ & $\begin{array}{l}106 \pm \\
5.2\end{array}$ & $\begin{array}{l}110 \pm \\
7.8\end{array}$ & & $\begin{array}{l}121 \pm \\
6.3\end{array}$ & $\begin{array}{l}117 \pm \\
7.3\end{array}$ & & & $\begin{array}{l}99 \pm \\
7.0\end{array}$ & $\begin{array}{l}88 \pm \\
7.1\end{array}$ & & $\begin{array}{l}100 \pm \\
17.9\end{array}$ & & & $\begin{array}{l}220 \pm \\
41.8\end{array}$ \\
\hline$C p$ & $\begin{array}{l}100 \pm \\
5.4\end{array}$ & $\begin{array}{l}93 \pm \\
8.2\end{array}$ & $\begin{array}{l}93 \pm \\
6.9\end{array}$ & & $\begin{array}{l}100 \pm \\
3.9\end{array}$ & $\begin{array}{l}156 \pm \\
6.3\end{array}$ & $\begin{array}{l}164 \pm \\
9.2\end{array}$ & $\begin{array}{l}150 \pm \\
8.4\end{array}$ & $\begin{array}{l}100 \pm \\
9.2\end{array}$ & $\begin{array}{l}110 \pm \\
8.0\end{array}$ & $\begin{array}{l}118 \pm \\
13.7\end{array}$ & $\begin{array}{l}103 \pm \\
9.8\end{array}$ & $\begin{array}{l}100 \pm \\
10.8\end{array}$ & & & $\begin{array}{l}146 \pm \\
18.4\end{array}$ \\
\hline Ctse & $\begin{array}{l}100 \pm \\
8.0\end{array}$ & $\begin{array}{l}145 \pm \\
10.2\end{array}$ & $\begin{array}{l}141 \pm \\
13.7\end{array}$ & $\begin{array}{l}148 \pm \\
14.4\end{array}$ & $\begin{array}{l}100 \pm \\
9.8\end{array}$ & $\begin{array}{l}175 \pm \\
7.4\end{array}$ & $\begin{array}{l}173 \pm \\
13.9\end{array}$ & $\begin{array}{l}177 \pm \\
8.7\end{array}$ & $\begin{array}{l}100 \pm \\
6.8\end{array}$ & $\begin{array}{l}148 \pm \\
6.8\end{array}$ & $\begin{array}{l}140 \pm \\
11.3\end{array}$ & $\begin{array}{l}154 \pm \\
8.4\end{array}$ & $\begin{array}{l}100 \pm \\
21.0\end{array}$ & & & $\begin{array}{l}156 \pm \\
11.4\end{array}$ \\
\hline Erbb3 & $\begin{array}{l}100 \pm \\
2.7\end{array}$ & $\begin{array}{l}134 \pm \\
5.1\end{array}$ & $\begin{array}{l}143 \pm \\
7.5\end{array}$ & $\begin{array}{l}128 \pm \\
6.5\end{array}$ & $\begin{array}{l}100 \pm \\
8.1\end{array}$ & $\begin{array}{l}120 \pm \\
5.1\end{array}$ & $\begin{array}{l}128 \pm \\
9.1\end{array}$ & $\begin{array}{l}114 \pm \\
5.6\end{array}$ & & $\begin{array}{l}140 \pm \\
7.8\end{array}$ & $\begin{array}{l}129 \pm \\
10.9\end{array}$ & $\begin{array}{l}147 \pm \\
10.3\end{array}$ & $\begin{array}{l}100 \pm \\
5.4\end{array}$ & $\begin{array}{l}128 \pm \\
4.0\end{array}$ & $\begin{array}{l}126 \pm \\
6.5\end{array}$ & $\begin{array}{l}130 \pm \\
4.6\end{array}$ \\
\hline Fcgr2b & $\begin{array}{l}100 \pm \\
3.2\end{array}$ & $\begin{array}{l}108 \pm \\
7.9\end{array}$ & $\begin{array}{l}103 \pm \\
6.4\end{array}$ & $\begin{array}{l}112 \pm \\
13.0\end{array}$ & $\begin{array}{l}100 \pm \\
9.0\end{array}$ & $\begin{array}{l}161 \pm \\
5.2\end{array}$ & $\begin{array}{l}163 \pm \\
12.0\end{array}$ & $\begin{array}{l}160 \pm \\
3.6\end{array}$ & & $\begin{array}{l}124 \pm \\
11.0\end{array}$ & $\begin{array}{l}125 \pm \\
19.8\end{array}$ & & $\begin{array}{l}100 \pm \\
20.8\end{array}$ & & & $\begin{array}{l}182 \pm \\
21.2\end{array}$ \\
\hline Fcgr2a & & $\begin{array}{l}119 \pm \\
4.8\end{array}$ & $\begin{array}{l}16 \pm \\
8\end{array}$ & $\begin{array}{l}120 \pm \\
7.7\end{array}$ & & $\begin{array}{l}130 \pm \\
4.2\end{array}$ & $\begin{array}{l}130 \pm \\
6.4\end{array}$ & & & $\begin{array}{l}115 \pm \\
3.8\end{array}$ & $\begin{array}{l}109 \pm \\
5.0\end{array}$ & & & & & $\begin{array}{l}147 \pm \\
22.8\end{array}$ \\
\hline $\begin{array}{l}\text { Hla- } \\
\text { dmb }\end{array}$ & $\begin{array}{l}100 \pm \\
4.6\end{array}$ & $\begin{array}{l}137 \pm \\
4.6\end{array}$ & $\begin{array}{l}133 \pm \\
5.2\end{array}$ & $\begin{array}{l}140 \pm \\
7.3\end{array}$ & $\begin{array}{l}100 \pm \\
3.9\end{array}$ & $\begin{array}{l}137 \pm \\
3.7\end{array}$ & $\begin{array}{l}139 \pm \\
5.9\end{array}$ & $\begin{array}{l}135 \pm \\
4.9\end{array}$ & & $\begin{array}{l}126 \pm \\
4.4\end{array}$ & $\begin{array}{l}115 \pm \\
6.6\end{array}$ & $\begin{array}{l}133 \pm \\
4.7\end{array}$ & $\begin{array}{l}100 \pm \\
3.3\end{array}$ & $\begin{array}{l}164 \pm \\
8.3\end{array}$ & $\begin{array}{l}157 \pm \\
13.7\end{array}$ & $\begin{array}{l}172 \pm \\
8.4\end{array}$ \\
\hline Hla-dra & $\begin{array}{l}100 \pm \\
7.9\end{array}$ & $\begin{array}{l}404 \pm \\
19.0\end{array}$ & $\begin{array}{l}418 \pm \\
28.1\end{array}$ & & & $\begin{array}{l}302 \pm \\
23.4\end{array}$ & $\begin{array}{l}325 \pm \\
47.0\end{array}$ & & $\begin{array}{l}100 \pm \\
9.7\end{array}$ & $\begin{array}{l}181 \pm \\
22.4\end{array}$ & $\begin{array}{l}190 \pm \\
43.4\end{array}$ & & $\begin{array}{l}100 \pm \\
24.0\end{array}$ & & & \\
\hline tsbp 1 & $\begin{array}{l}100 \pm \\
12.8\end{array}$ & $\begin{array}{l}168 \pm \\
9.6\end{array}$ & $\begin{array}{l}165 \pm \\
14.0\end{array}$ & $\begin{array}{l}170 \pm \\
13.6\end{array}$ & $\begin{array}{l}100 \pm \\
8.7\end{array}$ & $\begin{array}{l}209 \pm \\
11.0\end{array}$ & $\begin{array}{l}225 \pm \\
18.7\end{array}$ & $\begin{array}{l}197 \pm \\
13.0\end{array}$ & $\begin{array}{l}100 \pm \\
9.5\end{array}$ & $\begin{array}{l}109 \pm \\
11.5\end{array}$ & $\begin{array}{l}80 \pm \\
14.2\end{array}$ & & $\begin{array}{l}100 \pm \\
17.7\end{array}$ & $\begin{array}{l}287 \pm \\
25.1\end{array}$ & & $\begin{array}{l}258 \pm \\
40.9\end{array}$ \\
\hline Icam1 & $\begin{array}{l}100 \pm \\
5.5\end{array}$ & $\begin{array}{l}155 \pm \\
7.6\end{array}$ & $\begin{array}{l}168 \pm \\
11.9\end{array}$ & $\begin{array}{l}146 \pm \\
9.4\end{array}$ & $\begin{array}{l}100 \pm \\
5.6\end{array}$ & $\begin{array}{l}143 \pm \\
4.2\end{array}$ & $\begin{array}{l}164 \pm \\
13.3\end{array}$ & $\begin{array}{l}131 \pm \\
5.7\end{array}$ & & $\begin{array}{l}102 \pm \\
6.5\end{array}$ & $\begin{array}{l}100 \pm \\
13.5\end{array}$ & $\begin{array}{l}102 \pm \\
6.5\end{array}$ & $\begin{array}{l}100 \pm \\
11.1\end{array}$ & $\begin{array}{l}146 \pm \\
11.8\end{array}$ & $\begin{array}{l}145 \pm \\
16.7\end{array}$ & $\begin{array}{l}147 \pm \\
18.3\end{array}$ \\
\hline Lgals3 & $\begin{array}{l}100 \pm \\
4.9\end{array}$ & $\begin{array}{l}264 \pm \\
16.6\end{array}$ & $\begin{array}{l}262 \pm \\
21.4\end{array}$ & $\begin{array}{l}266 \pm \\
24.9\end{array}$ & $\begin{array}{l}100 \pm \\
7.3\end{array}$ & $\begin{array}{l}198 \pm \\
12.6\end{array}$ & $\begin{array}{l}218 \pm \\
16.3\end{array}$ & $\begin{array}{l}184 \pm \\
17.4\end{array}$ & & $\begin{array}{l}184 \pm \\
12.9\end{array}$ & $\begin{array}{l}163 \pm \\
10.0\end{array}$ & & $\begin{array}{l}100 \pm \\
21.4\end{array}$ & & & \\
\hline $\begin{array}{l}\text { Hla- } \\
\text { drb1 }\end{array}$ & $\begin{array}{l}100 \pm \\
11.0\end{array}$ & $\begin{array}{l}713 \pm \\
57.0\end{array}$ & $\begin{array}{l}712 \pm \\
96.9\end{array}$ & $\begin{array}{l}713 \pm \\
73.8\end{array}$ & $\begin{array}{l}100 \pm \\
9.7\end{array}$ & $\begin{array}{l}439 \pm \\
34.8\end{array}$ & $\begin{array}{l}477 \pm \\
73.9\end{array}$ & $\begin{array}{l}412 \pm \\
30.1\end{array}$ & & $\begin{array}{l}291 \pm \\
40.2\end{array}$ & $\begin{array}{l}225 \pm \\
44.4\end{array}$ & $\begin{array}{l}342 \pm \\
59.0\end{array}$ & $\begin{array}{l}100 \pm \\
7.6\end{array}$ & & & \\
\hline S100a6 & $\begin{array}{l}100 \pm \\
2.8\end{array}$ & $\begin{array}{l}203 \pm \\
11.5\end{array}$ & $\begin{array}{l}200 \pm \\
16.2\end{array}$ & $\begin{array}{l}206 \pm \\
16.9\end{array}$ & $\begin{array}{l}100 \pm \\
7.5\end{array}$ & $\begin{array}{l}221 \pm \\
13.4\end{array}$ & $\begin{array}{l}248 \pm \\
20.9\end{array}$ & $\begin{array}{l}202 \pm \\
15.5\end{array}$ & & $\begin{array}{l}110 \pm \\
8.3\end{array}$ & $\begin{array}{l}88 \pm \\
15.5\end{array}$ & $\begin{array}{l}123 \pm \\
7.4\end{array}$ & $\begin{array}{l}100 \pm \\
9.0\end{array}$ & $\begin{array}{l}152 \pm \\
13.1\end{array}$ & $\begin{array}{l}161 \pm \\
24.3\end{array}$ & $\begin{array}{l}145 \pm \\
15.5\end{array}$ \\
\hline T/r2 & $\begin{array}{l}100 \pm \\
6.3\end{array}$ & $\begin{array}{l}106 \pm \\
5.7\end{array}$ & $\begin{array}{l}109 \pm \\
9.8\end{array}$ & $\begin{array}{l}104 \pm \\
7.2\end{array}$ & $\begin{array}{l}100 \pm \\
11.2\end{array}$ & $\begin{array}{l}154 \pm \\
9.6\end{array}$ & $\begin{array}{l}166 \pm \\
18.9\end{array}$ & $\begin{array}{l}146 \pm \\
9.7\end{array}$ & $\begin{array}{l}100 \pm \\
16.6\end{array}$ & $\begin{array}{l}172 \pm \\
18.8\end{array}$ & $\begin{array}{l}166 \pm \\
36.7\end{array}$ & $\begin{array}{l}176 \pm \\
22.7\end{array}$ & $\begin{array}{l}100 \pm \\
13.0\end{array}$ & $\begin{array}{l}164 \pm \\
11.3\end{array}$ & $\begin{array}{l}155 \pm \\
19.2\end{array}$ & $\begin{array}{l}173 \pm \\
12.9\end{array}$ \\
\hline Trr4 & $\begin{array}{l}100 \pm \\
2.7\end{array}$ & $\begin{array}{l}135 \pm \\
8.1\end{array}$ & $\begin{array}{l}118 \pm \\
12.8 \\
\end{array}$ & $\begin{array}{l}143 \pm \\
9.7\end{array}$ & $\begin{array}{l}100 \pm \\
8.4\end{array}$ & $\begin{array}{l}196 \pm \\
9.5\end{array}$ & $\begin{array}{l}200 \pm \\
19.7 \\
\end{array}$ & $\begin{array}{l}193 \pm \\
9.6\end{array}$ & $\begin{array}{l}100 \pm \\
8.7\end{array}$ & $\begin{array}{l}119 \pm \\
4.0\end{array}$ & $\begin{array}{l}118 \pm \\
5.9 \\
\end{array}$ & $\begin{array}{l}120 \pm \\
5.7 \\
\end{array}$ & $\begin{array}{l}100 \pm \\
8.3\end{array}$ & $\begin{array}{l}151 \pm \\
10.1\end{array}$ & $\begin{array}{l}141 \pm \\
4.9\end{array}$ & $\begin{array}{l}160 \pm \\
19.7 \\
\end{array}$ \\
\hline T/r7 & $\begin{array}{l}100 \pm \\
3.5\end{array}$ & $\begin{array}{l}134 \pm \\
6.5\end{array}$ & $\begin{array}{l}134 \pm \\
17.2\end{array}$ & $\begin{array}{l}135 \pm \\
3.9\end{array}$ & $\begin{array}{l}100 \pm \\
8.1\end{array}$ & $\begin{array}{l}173 \pm \\
5.0\end{array}$ & $\begin{array}{l}174 \pm \\
9.6\end{array}$ & $\begin{array}{l}172 \pm \\
5.7\end{array}$ & $\begin{array}{l}100 \pm \\
11.6\end{array}$ & $\begin{array}{l}94 \pm \\
7.6\end{array}$ & $\begin{array}{l}95 \pm \\
11.6\end{array}$ & $\begin{array}{l}93 \pm \\
10.7\end{array}$ & $\begin{array}{l}100 \pm \\
13.3\end{array}$ & $\begin{array}{l}169 \pm \\
11.3\end{array}$ & $\begin{array}{l}165 \pm \\
16.6\end{array}$ & $\begin{array}{l}173 \pm \\
16.5\end{array}$ \\
\hline
\end{tabular}

were evenly distributed throughout DG, CA1 and CA3 in adult rats. Few $\mathrm{CD}^{+} 4^{+}$activated microglia were observed in adult hippocampi. In both aged cognitively intact and aged cognitively impaired rats, increased Iba1 immunoreactivity was apparent, as was a marked increase in the appearance of activated $\left(\mathrm{Iba} 1^{+} / \mathrm{CD} 74^{+}\right.$) microglia. CD74-imunoreactive cells were associated with both synaptic and cell body (granule/pyramidal) layers throughout all three hippocampal subregions.

Higher magnification of microglia revealed changes in both protein expression and morphological characteristics of activation (Figure 7A). Resting microglia were immunoreactive to Iba1 but not CD74, and had numerous thin, branched projections. Activated microglia 


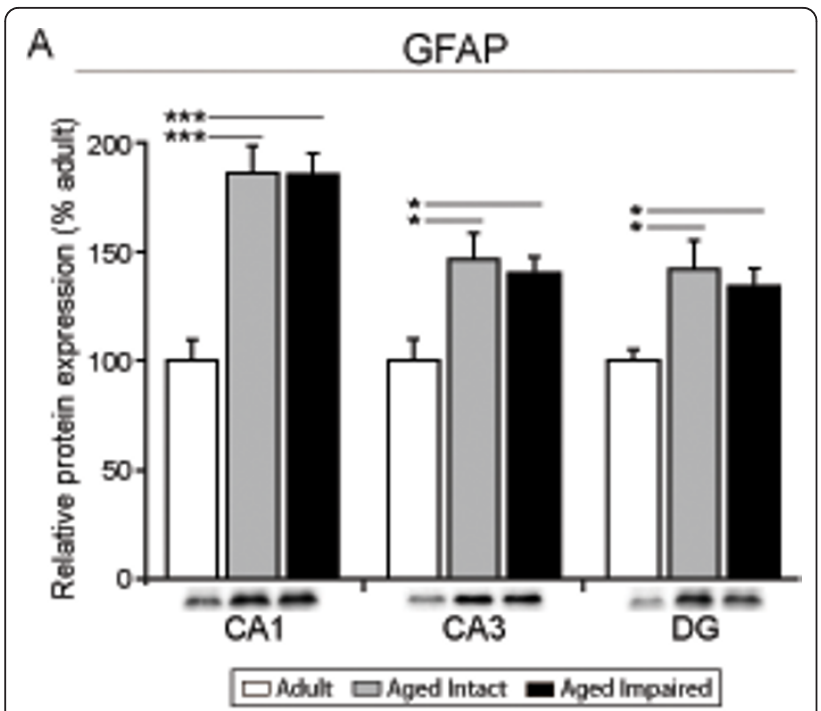

B

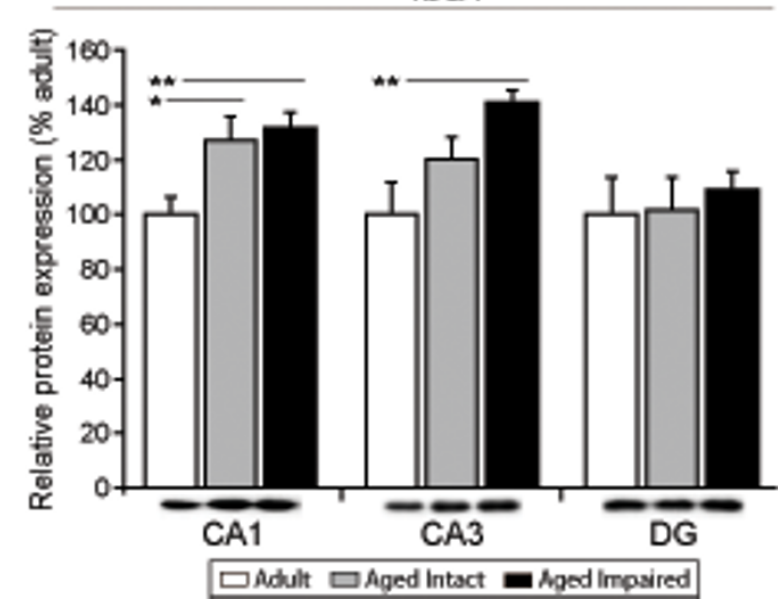

Figure 3 Age-related upregulation of hippocampal astrocyte and microglial activation protein markers. (A) Immunoblotting for GFAP, an intermediate filament protein expressed by astrocytes and upregulated with inflammation, is significantly increased in CA1, CA3 and DG of both aged cognitively intact and aged cognitively impaired rats compared to adults. (B) Ibal, a microglia-specific calcium binding and actin-bundling protein, is significantly induced in $C A 1$ and $C A 3$, but not DG of aged animals, regardless of cognitive status, compared to adults. Insets depict representative immunoblot images. ${ }^{*} p<0.05,{ }^{* *} p<0.01$, ${ }^{* *} p<0.001$, one-way ANOVA with Student Newman Keuls post hoc testing, $n=7-10$ /group.

expressing both Iba1 and CD74 exhibited characteristics of both mild activation (increased Iba1 immunoreactivity, weak CD74 immunoreactivity, enlarged somata) and moderate activation (increased Iba1 immunoreactivity, intense CD74 immunoreactivity, enlarged somata, thickened proximal processes, retracted distal processes). The percentage of mildly- and moderately-activated microglia relative to total microglia was calculated in each subregion of adult, aged intact, and aged impaired rats
(Figure 7B). The percentage of activated microglia in adult rats varied by subregion, with microglia in states of mild or moderate activation reflecting $1-2 \%$ of total microglia in CA1, 6\% in CA3, and 2-3\% in DG. Significant age-related increases in both mildly-activated and moderately activated microglia were evident in all three subregions of both cognitively intact and cognitively impaired aged rats compared to adults $(\mathrm{p}<0.001$, ANOVA, SNK), with no differences in either mild or moderate activation between aged intact and aged impaired groups. In CA1 of both aged intact and aged impaired rats, the percentage of both mildly- and moderately-activated microglia increased by approximately 8-fold, to $7-8 \%$ of total microglia. In CA3 of aged rats, $13-16 \%$ of microglia reflected either mild or moderate activation regardless of cognitive status, representing a 2.5 -fold increase in activation compared to adults. In DG of both aged intact and aged impaired rats, mild and moderate microglial activation increased by 6 -fold (12-13\% of total microglia) compared to adults. No correlation between the percentage of activated microglia (mild or moderate) and MWM performance was observed. No differences in the proportion of mildlyactivated to moderately-activated microglia were observed between groups in CA1, CA3 or DG. The density of microglia was the same $\left(\mathrm{Iba}^{+}\right.$cells $/ 100 \mu \mathrm{m}^{2}$ ) across groups (Figure 7B) indicating that the increase in activated microglial does not reflect proliferation or infiltration, but rather that an increased percentage of the existing microglial population is activated in the aged hippocampus.

Examination of the negative control slides incubated with secondary antibodies with primary antibodies omitted demonstrated that immunoreactivity to GFAP, Iba1, and CD74 was antigen-specific, as no non-specific background signal was detected on these controls (Figure 8).

\section{Discussion}

Neuroinflammation (i.e., expression of inflammatory response factors and glial activation), is a hallmark of brain aging [46,47] and is implicated in the cognitive deficits that accompany neurodegenerative conditions and profound brain insults (e.g., TBI and sepsis) [48-50]. Markers of neuroinflammation (e.g., CD74, GFAP) have been reported to increase in the hippocampus with age but the manner in which these changes may contribute to cognitive decline with normative aging remain to be determined. Here, we demonstrate that a coordinated induction of MHC II immune response-associated genes and concomitant astrocyte/microglial activation in the hippocampus occurs with advanced aging in both cognitively intact and impaired animals but does not correlate with age-related deficits of cognitive function. 


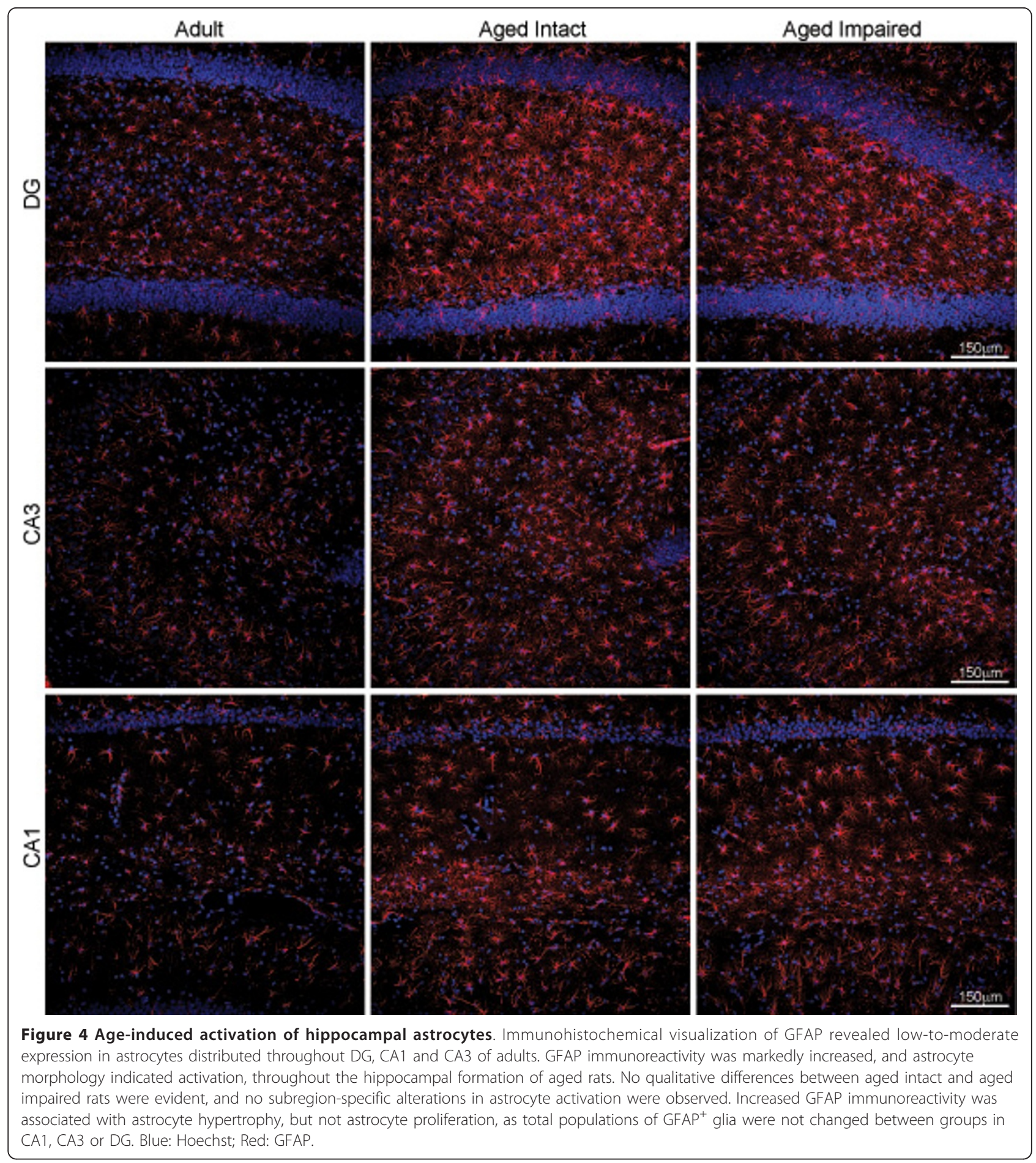

In this work, bioinformatic analysis of the hippocampal synaptosomal transcriptomes of adult and aged rats behaviorally assessed for spatial learning and memory identified 21 genes as components of an age-induced MHC II-associated antigen presentation and response pathway. Upregulation of these genes with advanced aging was confirmed by qPCR in whole-hippocampus synaptosome fractions and in hippocampal subregion (CA1, CA3 and DG) dissections. In agreement with our findings, examination of primary microarray datasets from previous transcriptomic studies of age-related changes in hippocampal gene expression from humans 


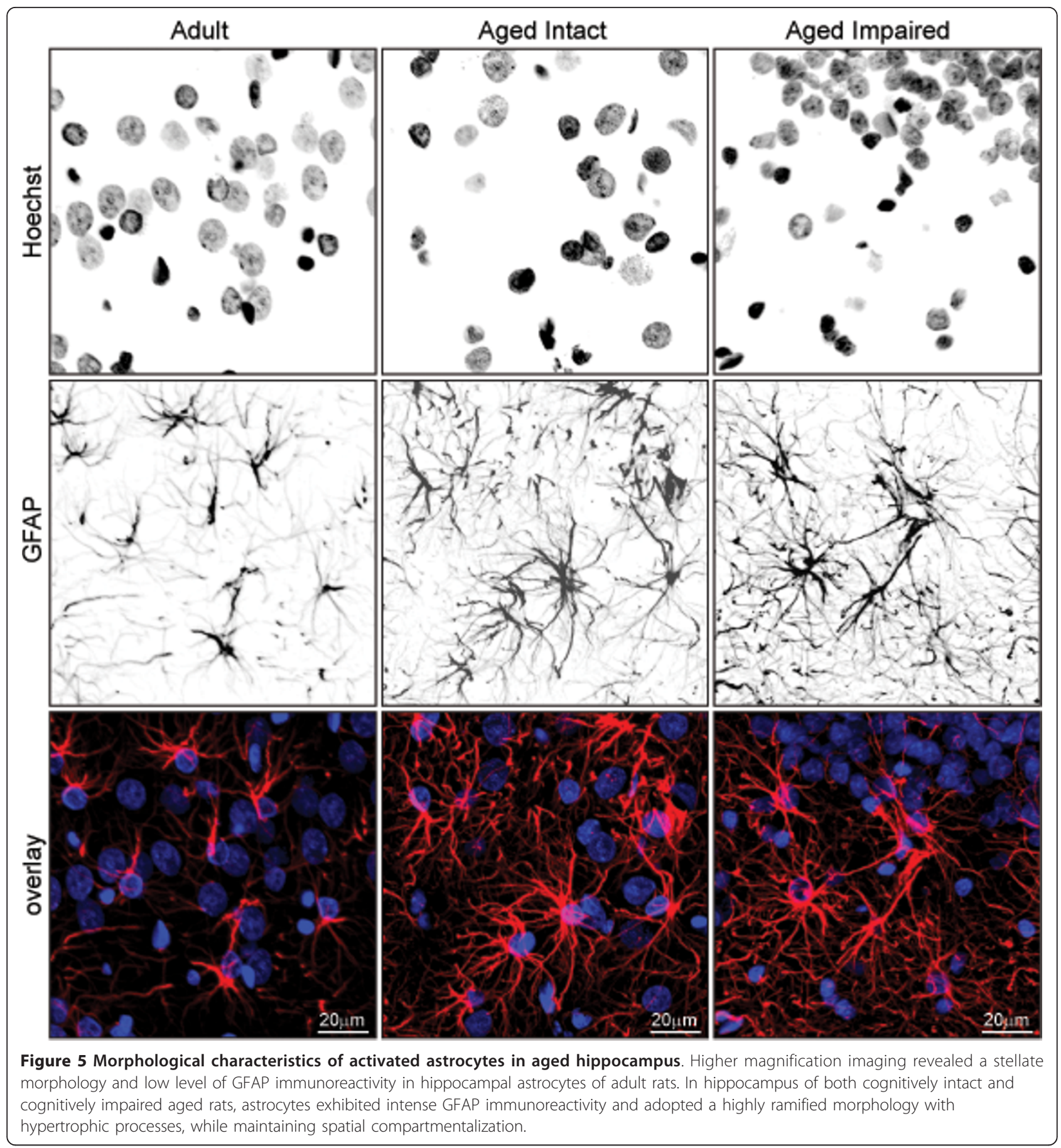

[51], non-human primates [52], and rodents [53,54] reveals upregulation of a number of immune response factors, including induction of MHC II-associated genes, that have not previously been systematically pursued in follow-up studies. For example, transcriptomic analyses of Fischer 344 rat hippocampal gene expression reveals age-related upregulation of MHC II alpha chain, Cd74,
Fcgr3, and C3 [55], as well as induction of MHC II beta and invariant chains and multiple complement components [56]. Importantly, no statistical relationships between age-related increases in these specific inflammation-response genes and cognitive performance were identified in these studies. Increased Cd74, C4a and C3 mRNA expression, which we observed in aged rats 


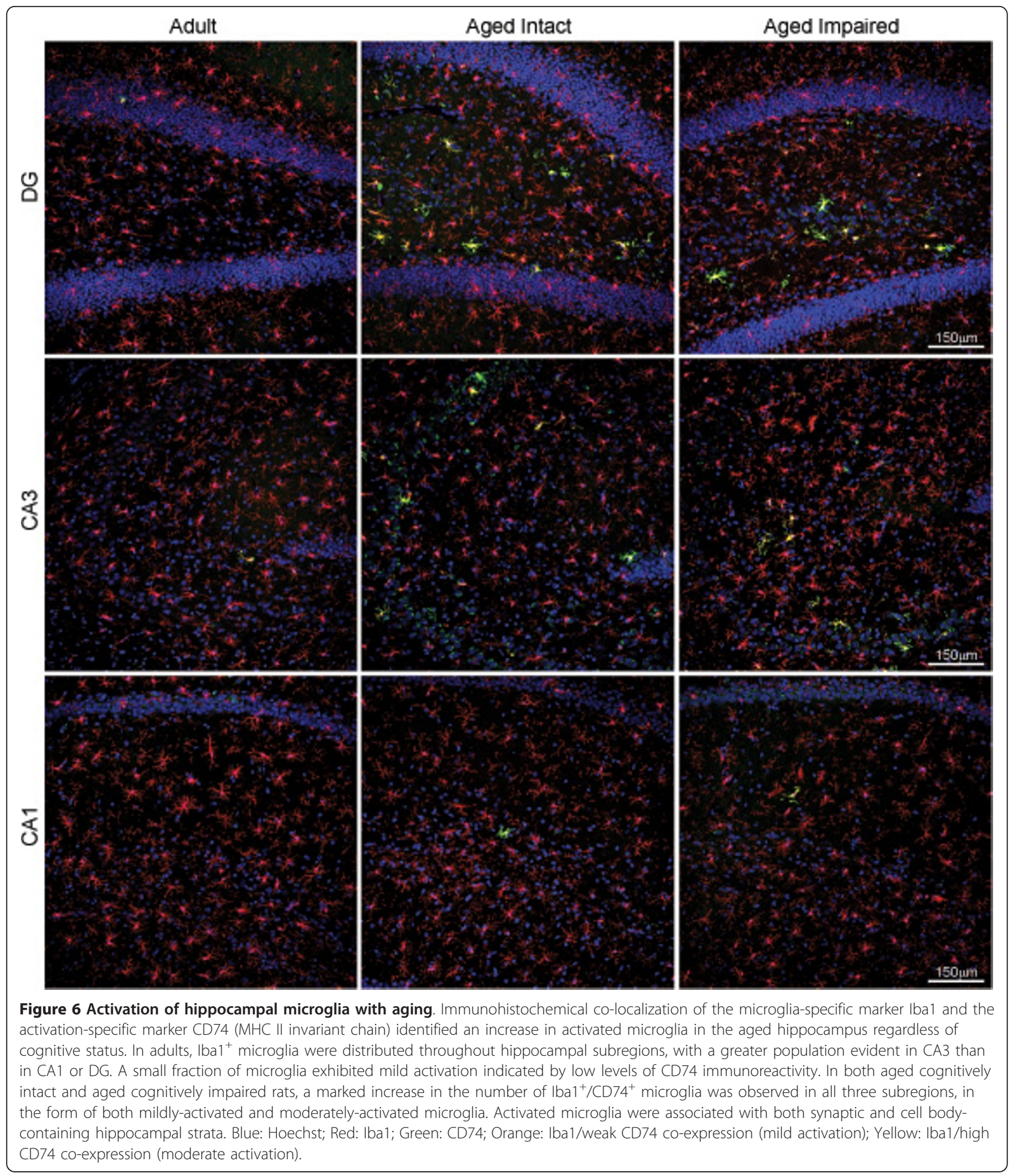

compared to 12-month old adults, has also been observed in the hippocampal transcriptome between young (4-6 months) and aged (24 months) Fischer 344 rats [57].

Our findings also share commonalities with previous targeted gene expression studies of hippocampal aging.
Increased hippocampal expression of Hla-dra has been reported in aged ( 24 months) versus young ( 3 months) Fischer $344 \times$ Brown Norway rats [58]. We have expanded on this work by demonstrating that increased expression of multiple MHC II components [i.e., MHC 


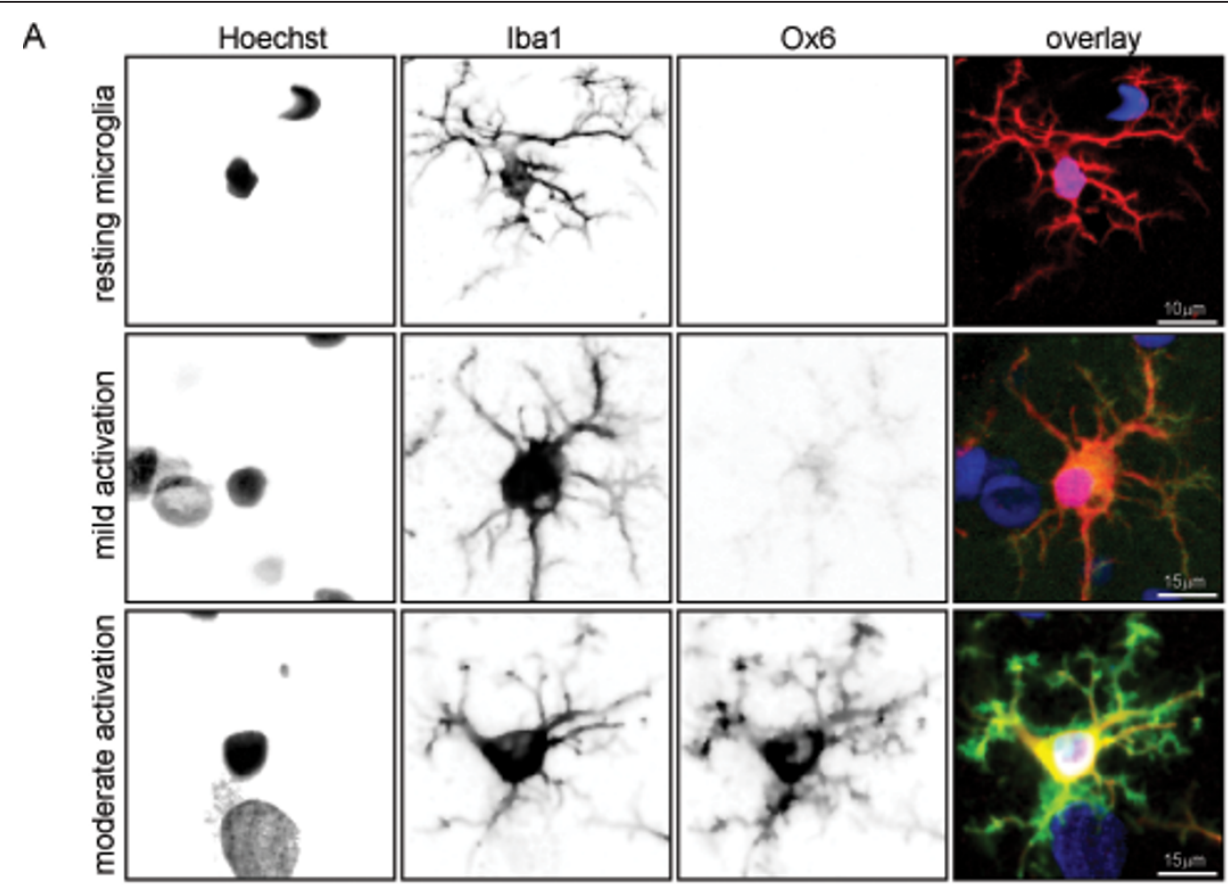

B
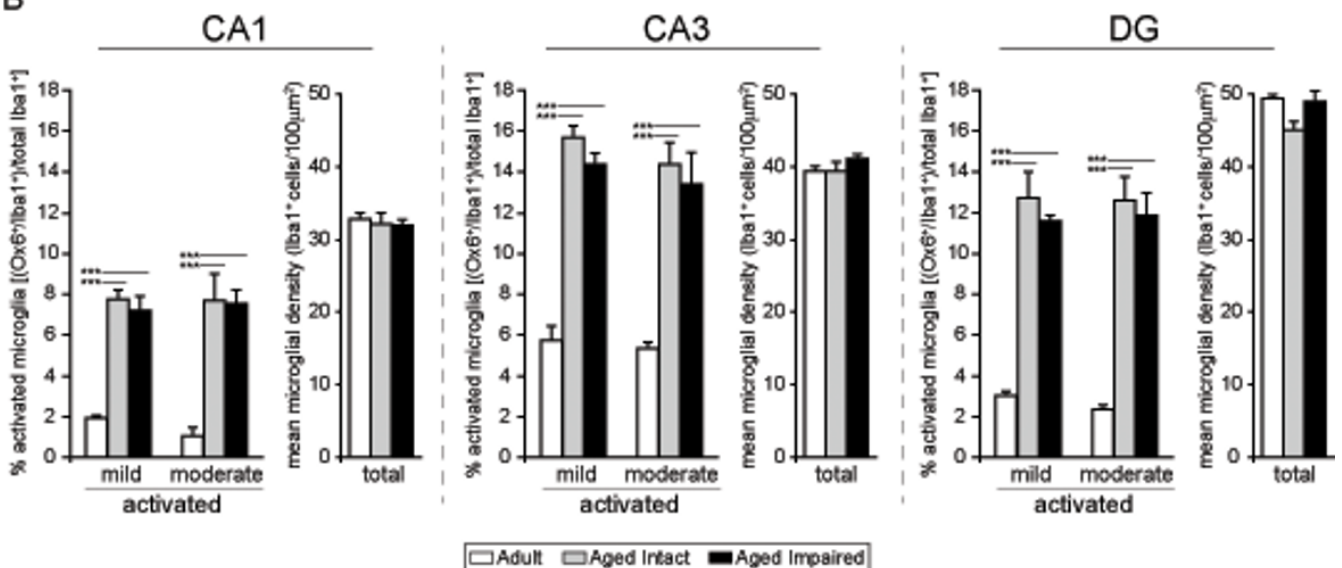

Figure 7 Age-related increase in activated microglial populations. (A) High-magnification visualization of resting/surveilling, or nonactivated, and activated microglia reveals differences in both immunoreactivity and morphology with aging. Non-activated microglia expressed Iba1 but not CD74, and had long, thin, branched processes. Microglia undergoing mild activation displayed increased Iba1 immunoreactivity, weak CD74 immunoreactivity, and enlarged somata, while moderately activated microglia demonstrated increased Iba1 immunoreactivity, intense CD74 immunoreactivity, enlarged somata, thickened proximal processes, and retracted distal processes. Notably, activated microglia maintained a ramified rather than ameboid morphology, indicating that microglial activation had not progressed to a reactive, phagocytic phenotype. (B) Quantitation of activated microglia (calculated as the ratio of $\mathrm{Iba} 1+/ \mathrm{CD} 74^{+}$to total $\mathrm{Iba} 1^{+}$cells) revealed significant increases in all three hippocampal subregions studied. In adult rats, a small fraction of total microglia were mildly or moderately activated in CA3, with far fewer activated microglia evident in CA1 and DG. The percentage of microglia undergoing mild or moderate activation was significantly increased, by several fold, throughout the hippocampus of both aged cognitively intact and aged cognitively impaired rats compared to adults. No differences between the degree of microglial activation (i.e., mild versus moderate) were observed between aged intact and aged impaired rats in CA1, CA3 or DG. Increased numbers of activated microglia in aged rats were not due to proliferation/infiltration, as total populations of microglia (Iba ${ }^{+}$ cells) were not different between groups. ${ }^{* *} \mathrm{p}<0.001$, one-way ANOVA with SNK post hoc testing. 


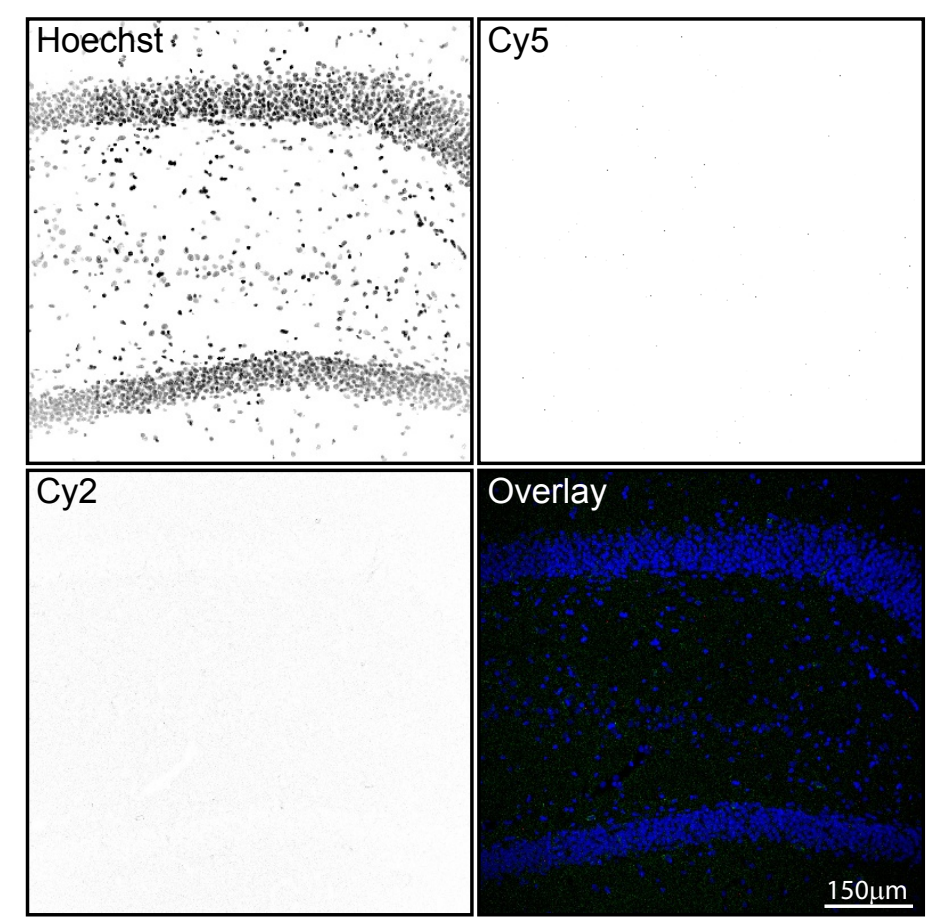

Figure 8 Assessment of negative control signals in immunohistochemical experiments. To ensure that visualization of astrocytes and microglia was not confounded by nonspecific secondary antibody binding, a negative control for the Cy2 (donkey-anti-mouse DyLight 488) and Cy5 (donkey-anti-rabbit DyLight 649) channels was included with primary antibodies omitted. Individual channels are presented as inverted gray scale. Weak, diffuse background signal was observed in the Cy2 channel, and no signal was apparent in the Cy5 channel. No nonspecific cell staining in the absence of primary antibodies occurred. Blue: Hoechst; Green: Cy2; Red: Cy5.

II alpha (Hla-dra), beta (Hla-drb1) and invariant (Cd74) chains, and the MHC II antigen-loading cofactor (Hla$\mathrm{dmb})$ ], and multiple MHC II pathway-associated genes occurs between mature adult (12 months) and aged (2628 months) rats. Similarly, the present study builds upon a previous finding of increased toll-like receptor (TLR) expression with aging in mouse whole-brain preparations [59], by demonstrating that increased expression of TLRs 3,4 , and 7 occurs primarily in hippocampal synapses and in the hippocampal CA3 subregion, and that TLR expression does not correlate with cognitive impairment.

Our findings extend these previous reports by characterizing a large set of MHC II components and associated immune/inflammation response factors and by demonstrating that increased expression of these genes occurs in both cognitively intact and impaired animals but that the extent of induction does not correlate with cognitive deficits. Interestingly, the magnitude of induction of these MHC II-mediated immune response genes was greater in CA1 and CA3 than in DG in nearly all cases, suggesting that pyramidal cell-containing subregions may undergo age-related neuroinflammation to a greater extent than granule cell-containing regions. Further, age-related increases in immune/inflammation response gene expression were, in many cases, larger in hippocampal synaptosome fractions than in dissected hippocampal subregions. MHC II pathway gene expression in hippocampal synaptosomes likely stems largely from astrocytic and microglial processes closely associated with synaptic compartments, while downstream inflammatory signaling factors may derive from the synaptic terminals themselves. This suggests that heightened antigen processing/immune response within the synaptic milieu may contribute to age-related dysfunction of hippocampal synapses and potentially plays a role in synapse loss [60-62].

Immunohistochemical studies of both human and nonhuman primate aging have demonstrated upregulation of MHC II alpha/beta chains in hippocampal microglia $[18,21,63,64]$. We have observed, in both aged cognitively intact and aged cognitively impaired rats, widespread mild and moderate microglial activation indicated by increased numbers of microglia expressing CD74 (i.e., the MHC II invariant chain), and altered morphological and immunoreactive phenotypes. While the percentage of activated microglia (reflecting the ratio of $\mathrm{CD} 74^{+} / \mathrm{Iba}^{+}$to total Iba $1^{+}$microglia) was consistently increased by several fold in all aged rats compared to adults, these glia maintained a ramified morphology, rather than the ameboid, 
morphology typical of a phagocytic phenotype. This suggests that the neuroinflammatory state in the aged hippocampus, while elevated compared to adults, is not severe enough to induce a transition from a "surveilling" microglial phenotype $[65,66]$ to the reactive phenotype associated with dramatic CNS insults and neurodegeneration [66-68]. In agreement with previous work, the total number of microglia ( $\mathrm{Iba}^{+}$cells) did not increase with aging [69], indicating that increases in Iba1 protein expression and numbers of $\mathrm{CD} 74+$ microglia reflect age-related activation rather than microglial proliferation or infiltration. Iba1/ CD74 co-labeling extends previous findings of increased hippocampal microglial activation (CD74+ only) in comparisons of young (3-6 months) and aged (24+ months) $[70,71]$ by demonstrating that an increased percentage of total hippocampal microglia are activated with advanced aging compared to mature adults. Additionally, previous studies [70-72] have generally compared young (3-6 months) and old (24+ months) rats, while our results demonstrate that microglial activation occurs between mature adulthood (12 months) and advanced age (24-26 months). Furthermore, we extend a previous finding of qualitative differences in populations of activated microglia in the aged Wistar rat hippocampus [70] by demonstrating that increased activation is evident across CA1, CA3, and DG, and that, within each subregion, the percentages of qualitatively distinct activated microglia (mild and moderate) are equivalent. Similar to the work by Gavilan and colleagues [70], fewer activated microglia were observed in close proximity to pyramidal and granule cell layers than associated with synapse-containing hippocampal layers. While adding to the evidence of hippocampal microglial activation with advanced aging, our findings also clearly demonstrate that the examined marker of microglial activation (CD74) is not directly associated with deficits of spatial learning and maze performance, in agreement with previous studies in the Long Evans rat [72].

We also observed increased astrocyte activation, as indicated by increased GFAP expression and morphological alterations, which occurred in the absence of astrocyte proliferation. Studies of humans, nonhuman primates, and rodent models of human aging have demonstrated increased glial fibrillary acidic protein (GFAP) gene and protein expression indicative of astrocyte activation and age-related astrocyte hypertrophy, in agreement with our findings [73-79]. Our observations agree with one of the first investigations of age-related hippocampal astrocyte activation, which demonstrated that these dystrophic astrocyte processes are often oriented in the same direction [77]. Our work also revealed that while astrocyte activation increases throughout the hippocampus with advanced aging, no cognitive decline-associated differences in GFAP protein content or numbers of $\mathrm{GFAP}^{+}$astrocytes are apparent between aged intact and aged impaired rats.
Our finding that MHC II pathway induction and glial activation occur in aged rats regardless of cognitive status raises the important question of whether neuroinflammation plays a role in the pathogenesis of cognitive decline [47]. Pathological gliosis and inflammation are associated with severe cognitive dysfunction in neurodegenerative/ advanced disease states, traumatic brain injury, and direct inflammatory stimulation [17-24]. Hippocampal neuroinflammation has also been suggested to play a functional role in the etiology of age-related cognitive impairment [80,81]. A lesser degree of neuroinflammation occurs with normative aging than with disease or injury, and ranges from increased oxidative stress to induction of inflammatory signal transducing factors including cytokines, chemokines, complement, and stress response proteins which we and others have previously described in studies of hippocampal aging [12,25,27,55,82-84]. Agerelated alterations in these factors suggest an allostatic shift toward a heightened basal neuroinflammatory state in the aging hippocampus. Establishment and maintenance of such a state has been termed "para-inflammation" and is thought to represent an adaptive response to persistent sub-threshold stimuli such as cellular/tissue stress [45].

The present work demonstrates that, while neuroinflammation at the level of MHC II pathway expression and glial activation may represent an aspect of agerelated hippocampal dysregulation necessary for development of cognitive deficits, these measures do not correlate to cognitive performance deficits. It is likely that multiple age-related processes, including decreased neurotransmission, glial dysfunction, and increased neuroinflammation, combine with cognitive decline-related dysregulation of plasticity- and myelin-associated proteins and genes [27,55], to form an additive array of insults to impede healthy neuronal function and learning and memory [3]. Thus far, the triggering event(s) that cause the transition from an aged, cognitively intact state to an aged, cognitively impaired state have remained elusive. Additionally, the potential remains that other measures of neuroinflammation, including cytokines in both the CNS and systemically could directly correlate to impaired spatial learning and memory. The importance of the interplay between systemic inflammation, neuroinflammation, and brain function with aging was recently underscored by a report demonstrating inhibition of hippocampal neurogenesis by the systemic cytokine CCL11 [85]. Ultimately, our understanding of the functional roles of neuroinflammation in both protective and harmful CNS processes must advance in order to identify whether there are appropriate points for interventions seeking modulate age-related neuroinflammation with the goal of preventing or reversing age-related hippocampal dysfunction. 


\section{Conclusions}

These data demonstrate the age-related induction of mild to moderate neuroinflammation with aging in multiple regions of the hippocampus. Analysis of neuroinflammatory measures (MHC II pathway-associated gene expression, and astrocyte and microglial activation) in rats assessed for spatial learning and memory by Morris water maze testing revealed a lack of correlation between inflammation and behavioral performance, suggesting that these aspects of hippocampal neuroinflammation alone are not sufficient to induce age-related impairment of spatial learning and memory. Future work building on this demonstration of age-related induction of MHC II pathway and inflammatory response factor expression and glial activation in both cognitively intact and cognitively impaired aged animals will need to examine if and how age-related hippocampal changes such as those described here combine with cognition-specific alterations to ultimately impair spatial learning and memory.

\section{Abbreviations}

CA1: cornu ammonis 1; CA3: cornu ammonis 3; DG: dentate gyrus; MHC II: major histocompatibility complex class II; CLIP: class II-associated invariant chain peptide; GFAP: glial fibrillary acidic protein; Iba1: ionized calcium binding adaptor molecule 1: SNK: Student Newman Keuls; BHMTC: Benjamini-Hochberg multiple testing correction

\section{Acknowledgements}

This work was support by funding from the National Institute on Aging, National Institutes of Health (5R01AG026607) and Donald W. Reynolds Foundation. The authors wish to thank Winston Wolfe for technical assistance.

\section{Author details}

'Department of Pharmacology, Pennsylvania State University College of Medicine, 500 University Drive, Hershey, Pennsylvania, 17057, USA. ²Donald W. Reynolds Department of Geriatric Medicine, Reynolds Oklahoma Center on Aging, University of Oklahoma Health Sciences Center, 975 NE $10^{\text {th }}$ Street, BRC-1303, Oklahoma City, Oklahoma, 73104, USA.

\section{Authors' contributions}

HDV, WMF, and WES conceived and designed the studies. JAF conducted behavioral testing, and HY and JPW performed hippocampus dissections. HDV, GVB, RMB executed and analyzed the experiments. HDV and WMF wrote, and all authors edited, read, and approved the final manuscript.

\section{Competing interests}

The authors declare that they have no competing interests.

Received: 27 July 2011 Accepted: 11 October 2011

Published: 11 October 2011

\section{References}

1. Schaie KW: Intellectual Development in Adulthood: The Seattle Longitudinal Study Cambridge: Cambridge University Press; 1996.

2. Hedden T, Gabrieli JD: Insights into the ageing mind: a view from cognitive neuroscience. Nat Rev Neurosci 2004, 5:87-96.

3. Vanguilder HD, Freeman WM: The hippocampal neuroproteome with aging and cognitive decline: past progress and future directions. Front Aging Neurosci 2011, 3:8.

4. Shing YL, Rodrigue KM, Kennedy KM, Fandakova Y, Bodammer N, WerkleBergner M, Lindenberger U, Raz N: Hippocampal subfield volumes: age, vascular risk, and correlation with associative memory. Front Aging Neurosci 2011, 3:2

5. Poe BH, Linville C, Riddle DR, Sonntag WE, Brunso-Bechtold JK: Effects of age and insulin-like growth factor- 1 on neuron and synapse numbers in area CA3 of hippocampus. Neuroscience 2001, 107:231-238.

6. Kantarci K, Senjem ML, Lowe VJ, Wiste HJ, Weigand SD, Kemp BJ, Frank AR, Shiung MM, Boeve BF, Knopman DS, Petersen RC, Jack CR Jr: Effects of age on the glucose metabolic changes in mild cognitive impairment. AJNR Am J Neuroradiol 2010, 31:1247-1253.

7. O'Callaghan RM, Griffin EW, Kelly AM: Long-term treadmill exposure protects against age-related neurodegenerative change in the rat hippocampus. Hippocampus 2009, 19:1019-1029.

8. Squier TC: Oxidative stress and protein aggregation during biological aging. Exp Gerontol 2001, 36:1539-1550.

9. Sonntag WE, Lynch CD, Cooney PT, Hutchins PM: Decreases in cerebra microvasculature with age are associated with the decline in growth hormone and insulin-like growth factor 1. Endocrinology 1997 138:3515-3520.

10. Gavilan MP, Vela J, Castano A, Ramos B, del Rio JC, Vitorica J, Ruano D: Cellular environment facilitates protein accumulation in aged rat hippocampus. Neurobiol Aging 2006, 27:973-982.

11. Shi L, Linville MC, Tucker EW, Sonntag WE, Brunso-Bechtold JK: Differential effects of aging and insulin-like growth factor- 1 on synapses in CA1 of rat hippocampus. Cereb Cortex 2005, 15:571-577.

12. Vanguilder HD, Yan H, Farley JA, Sonntag WE, Freeman WM: Aging alters the expression of neurotransmission-regulating proteins in the hippocampal synaptoproteome. J Neurochem 2010, 113:1577-1588.

13. Ben Achour S, Pascual O: Glia: the many ways to modulate synaptic plasticity. Neurochem Int 2010, 57:440-445.

14. Bessis A, Bechade C, Bernard D, Roumier A: Microglial control of neuronal death and synaptic properties. Glia 2007, 55:233-238.

15. Neumann H, Kotter MR, Franklin RJ: Debris clearance by microglia: an essential link between degeneration and regeneration. Brain 2009, 132:288-295.

16. Streit WJ: Microglial-neuronal interactions. J Chem Neuroanat 1993 6:261-266.

17. Buchanan JB, Sparkman NL, Chen J, Johnson RW: Cognitive and neuroinflammatory consequences of mild repeated stress are exacerbated in aged mice. Psychoneuroendocrinology 2008, 33:755-765.

18. Godbout JP, Chen J, Abraham J, Richwine AF, Berg BM, Kelley KW, Johnson RW: Exaggerated neuroinflammation and sickness behavior in aged mice following activation of the peripheral innate immune system. FASEB J 2005, 19:1329-1331.

19. Hein AM, Stasko MR, Matousek SB, Scott-McKean JJ, Maier SF, Olschowka JA, Costa AC, O'Banion MK: Sustained hippocampal IL-1beta overexpression impairs contextual and spatial memory in transgenic mice. Brain Behav Immun 2010, 24:243-253.

20. Huang Y, Henry CJ, Dantzer R, Johnson RW, Godbout JP: Exaggerated sickness behavior and brain proinflammatory cytokine expression in aged mice in response to intracerebroventricular lipopolysaccharide. Neurobiol Aging 2008, 29:1744-1753.

21. Sloane JA, Hollander W, Moss MB, Rosene DL, Abraham CR: Increased microglial activation and protein nitration in white matter of the aging monkey. Neurobiol Aging 1999, 20:395-405.

22. Fuller S, Steele M, Munch G: Activated astroglia during chronic inflammation in Alzheimer's disease-do they neglect their neurosupportive roles? Mutat Res 2010, 690:40-49.

23. Peters O, Schipke CG, Philipps A, Haas B, Pannasch U, Wang LP, Benedetti B, Kingston $A E$, Kettenmann $\mathrm{H}$ : Astrocyte function is modified by Alzheimer's disease-like pathology in aged mice. J Alzheimers Dis 2009, 18:177-189.

24. Wilson CJ, Finch CE, Cohen HJ: Cytokines and cognition-the case for a head-to-toe inflammatory paradigm. J Am Geriatr Soc 2002, 50:2041-2056.

25. Freeman WM, Vanguilder HD, Bennett C, Sonntag WE: Cognitive performance and age-related changes in the hippocampal proteome. Neuroscience 2009, 159:183-195.

26. Gallagher M, Rapp PR: The use of animal models to study the effects of aging on cognition. Annu Rev Psychol 1997, 48:339-370.

27. Vanguilder HD, Farley JA, Yan H, Van Kirk CA, Mitschelen M, Sonntag WE, Freeman WM: Hippocampal dysregulation of synaptic plasticity- 
associated proteins with age-related cognitive decline. Neurobiol Dis 2011, 43:201-212.

28. Gorelick PB: Role of inflammation in cognitive impairment: results of observational epidemiological studies and clinical trials. Ann N Y Acad Sci 2010, 1207:155-162.

29. Comim CM, Constantino LC, Barichello T, Streck EL, Quevedo J, Dal-Pizzol F: Cognitive impairment in the septic brain. Curr Neurovasc Res 2009, 6:194-203

30. Bianchi ME: DAMPs, PAMPs and alarmins: all we need to know about danger. J Leukoc Biol 2007, 81:1-5.

31. Rocha N, Neefjes J: MHC class II molecules on the move for successful antigen presentation. EMBO J 2008, 27:1-5.

32. Aloisi F, Ria F, Penna G, Adorini L: Microglia are more efficient than astrocytes in antigen processing and in Th1 but not Th2 cell activation. $\mathrm{J}$ Immunol 1998, 160:4671-4680.

33. Hamo L, Stohlman SA, Otto-Duessel M, Bergmann CC: Distinct regulation of $\mathrm{MHC}$ molecule expression on astrocytes and microglia during viral encephalomyelitis. Glia 2007, 55:1169-1177.

34. Conde JR, Streit WJ: Microglia in the aging brain. J Neuropathol Exp Neurol 2006, 65:199-203.

35. Tremblay ME, Majewska AK: A role for microglia in synaptic plasticity? Commun Integr Biol 2011, 4:220-222.

36. Bruce-Keller AJ: Microglial-neuronal interactions in synaptic damage and recovery. J Neurosci Res 1999, 58:191-201.

37. Lee SC, Moore GR, Golenwsky G, Raine CS: Multiple sclerosis: a role for astroglia in active demyelination suggested by class II MHC expression and ultrastructural study. J Neuropathol Exp Neurol 1990, 49:122-136.

38. Mitschelen M, Garteiser P, Carnes BA, Farley JA, Doblas S, Demoe JH, Warrington JP, Yan H, Nicolle MM, Towner R, Sonntag WE: Basal and hypercapnia-altered cerebrovascular perfusion predict mild cognitive impairment in aging rodents. Neuroscience 2009, 164:918-928.

39. Maei HR, Zaslavsky K, Teixeira CM, Frankland PW: What is the Most Sensitive Measure of Water Maze Probe Test Performance? Front Integr Neurosci 2009, 3:4.

40. Terry AV Jr: Spatial Navigation (Water Maze) Tasks. In Methods of Behavior Analysis in Neuroscience.. second edition. Edited by: Buccafusco JJ. Boca Raton: CRC Press; 2009:

41. Newton IG, Forbes ME, Legault C, Johnson JE, Brunso-Bechtold JK, Riddle DR: Caloric restriction does not reverse aging-related changes in hippocampal BDNF. Neurobiol Aging 2005, 26:683-688.

42. Brucklacher RM, Patel KM, Vanguilder HD, Bixler GV, Barber AJ, Antonetti DA, Lin CM, LaNoue KF, Gardner TW, Bronson SK, Freeman WM: Whole genome assessment of the retinal response to diabetes reveals a progressive neurovascular inflammatory response. BMC Med Genomics 2008, 1:26.

43. Vanguilder HD, Bixler GV, Kutzler L, Brucklacher RM, Bronson SK, Kimball SR, Freeman WM: Multi-modal proteomic analysis of retinal protein expression alterations in a rat model of diabetic retinopathy. PLOS One 2011, 6:e16271.

44. Bixler GV, Vanguilder HD, Brucklacher RM, Kimball SR, Bronson SK, Freeman WM: Chronic insulin treatment of diabetes does not fully normalize alterations in the retinal transcriptome. BMC Med Genomics 2011, 4:40.

45. Medzhitov R: Origin and physiological roles of inflammation. Nature 2008, 454:428-435.

46. de Magalhaes JP, Curado J, Church GM: Meta-analysis of age-related gene expression profiles identifies common signatures of aging. Bioinformatics 2009, 25:875-881.

47. Lucin KM, Wyss-Coray T: Immune activation in brain aging and neurodegeneration: too much or too little? Neuron 2009, 64:110-122.

48. Khandaker GM, Jones PB: Cognitive and functional impairment after severe sepsis. JAMA 2011, 305:673-674.

49. Brooks WM, Stidley CA, Petropoulos H, Jung RE, Weers DC, Friedman SD Barlow MA, Sibbitt WL, Yeo RA: Metabolic and cognitive response to human traumatic brain injury: a quantitative proton magnetic resonance study. J Neurotrauma 2000, 17:629-640.

50. Dash PK, Orsi SA, Zhang M, Grill RJ, Pati S, Zhao J, Moore AN: Valproate administered after traumatic brain injury provides neuroprotection and improves cognitive function in rats. PLOS One 2010, 5:e11383.

51. Berchtold NC, Cribbs DH, Coleman PD, Rogers J, Head E, Kim R, Beach T, Miller C, Troncoso J, Trojanowski JQ, Zielke HR, Cotman CW: Gene expression changes in the course of normal brain aging are sexually dimorphic. Proc Natl Acad Sci USA 2008, 105:15605-15610.

52. Blalock EM, Grondin R, Chen KC, Thibault O, Thibault V, Pandya JD, Dowling A, Zhang Z, Sullivan P, Porter NM, Landfield PW: Aging-related gene expression in hippocampus proper compared with dentate gyrus is selectively associated with metabolic syndrome variables in rhesus monkeys. J Neurosci 2010, 30:6058-6071.

53. Terao A, Apte-Deshpande A, Dousman L, Morairty S, Eynon BP, Kilduff TS, Freund YR: Immune response gene expression increases in the aging murine hippocampus. J Neuroimmunol 2002, 132:99-112.

54. Lee CK, Weindruch R, Prolla TA: Gene-expression profile of the ageing brain in mice. Nat Genet 2000, 25:294-297.

55. Blalock EM, Chen KC, Sharrow K, Herman JP, Porter NM, Foster TC, Landfield PW: Gene microarrays in hippocampal aging: statistical profiling identifies novel processes correlated with cognitive impairment. J Neurosci 2003, 23:3807-3819.

56. Kadish I, Thibault O, Blalock EM, Chen KC, Gant JC, Porter NM, Landfield PW Hippocampal and cognitive aging across the lifespan: a bioenergetic shift precedes and increased cholesterol trafficking parallels memory impairment. J Neurosci 2009, 29:1805-1816.

57. Rowe WB, Blalock EM, Chen KC, Kadish I, Wang D, Barrett JE, Thibault O, Porter NM, Rose GM, Landfield PW: Hippocampal expression analyses reveal selective association of immediate-early, neuroenergetic, and myelinogenic pathways with cognitive impairment in aged rats. $J$ Neurosci 2007, 27:3098-3110.

58. Frank MG, Barrientos RM, Biedenkapp JC, Rudy JW, Watkins LR, Maier SF: mRNA up-regulation of MHC II and pivotal pro-inflammatory genes in normal brain aging. Neurobiol Aging 2006, 27:717-722.

59. Letiembre M, Hao W, Liu Y, Walter S, Mihaljevic I, Rivest S, Hartmann T, Fassbender $\mathrm{K}$ : Innate immune receptor expression in normal brain aging. Neuroscience 2007, 146:248-254.

60. Kumar A, Foster TC: Neurophysiology of Old Neurons and Synapses. In Brain Aging: Models, Methods, and Mechanisms. Edited by: Riddle DR. Boca Raton: CRC Press; 2007:.

61. Kumar A, Thinschmidt JS, Foster TC, King MA: Aging effects on the limits and stability of long-term synaptic potentiation and depression in rat hippocampal area CA1. J Neurophysiol 2007, 98:594-601.

62. Barnes CA, Suster MS, Shen J, McNaughton BL: Multistability of cognitive maps in the hippocampus of old rats. Nature 1997, 388:272-275.

63. Sheffield LG, Berman NE: Microglial expression of MHC class II increases in normal aging of nonhuman primates. Neurobiol Aging 1998, 19:47-55.

64. Simpson JE, Ince PG, Higham CE, Gelsthorpe CH, Fernando MS, Matthews F, Forster G, O'Brien JT, Barber R, Kalaria RN, Brayne C, Shaw PJ, Stoeber K, Williams GH, Lewis CE, Wharton SB: Microglial activation in white matter lesions and nonlesional white matter of ageing brains. Neuropathol Appl Neurobiol 2007, 33:670-683.

65. Hanisch UK, Kettenmann H: Microglia: active sensor and versatile effector cells in the normal and pathologic brain. Nat Neurosci 2007, 10:1387-1394.

66. Nimmerjahn A, Kirchhoff F, Helmchen F: Resting microglial cells are highly dynamic surveillants of brain parenchyma in vivo. Science 2005, 308:1314-1318.

67. Neniskyte U, Neher JJ, Brown GC: Neuronal death induced by nanomolar amyloid beta is mediated by primary phagocytosis of neurons by microglia. J Biol Chem 2011, E-Published.

68. Witting A, Muller P, Herrmann A, Kettenmann H, Nolte C: Phagocytic clearance of apoptotic neurons by Microglia/Brain macrophages in vitro: involvement of lectin-, integrin-, and phosphatidylserine-mediated recognition. J Neurochem 2000, 75:1060-1070.

69. Long JM, Kalehua AN, Muth NJ, Calhoun ME, Jucker M, Hengemihle JM, Ingram DK, Mouton PR: Stereological analysis of astrocyte and microglia in aging mouse hippocampus. Neurobiol Aging 1998, 19:497-503.

70. Gavilan MP, Revilla E, Pintado C, Castano A, Vizuete ML, Moreno-Gonzalez I, Baglietto-Vargas D, Sanchez-Varo R, Vitorica J, Gutierrez A, Ruano D: Molecular and cellular characterization of the age-related neuroinflammatory processes occurring in normal rat hippocampus: potential relation with the loss of somatostatin GABAergic neurons. J Neurochem 2007, 103:984-996.

71. Ogura K, Ogawa M, Yoshida M: Effects of ageing on microglia in the normal rat brain: immunohistochemical observations. Neuroreport 1994, 5:1224-1226. 
72. Nicolle MM, Gonzalez J, Sugaya K, Baskerville KA, Bryan D, Lund K, Gallagher M, McKinney M: Signatures of hippocampal oxidative stress in aged spatial learning-impaired rodents. Neuroscience 2001, 107:415-431.

73. Bernal GM, Peterson DA: Phenotypic and gene expression modification with normal brain aging in GFAP-positive astrocytes and neural stem cells. Aging Cell 2011, 10:466-482.

74. Bjorklund H, Eriksdotter-Nilsson M, Dahl D, Rose G, Hoffer B, Olson L: Image analysis of GFA-positive astrocytes from adolescence to senescence. Exp Brain Res 1985, 58:163-170.

75. David JP, Ghozali F, Fallet-Bianco C, Wattez A, Delaine S, Boniface B, Di MC, Delacourte A: Glial reaction in the hippocampal formation is highly correlated with aging in human brain. Neurosci Lett 1997, 235:53-56.

76. Geinisman Y, Bondareff W, Dodge JT: Hypertrophy of astroglial processes in the dentate gyrus of the senescent rat. Am J Anat 1978, 153:537-543.

77. Landfield PW, Rose G, Sandles L, Wohlstadter TC, Lynch G: Patterns of astroglial hypertrophy and neuronal degeneration in the hippocampus of ages, memory-deficient rats. J Gerontol 1977, 32:3-12

78. O'Callaghan JP, Miller DB: The concentration of glial fibrillary acidic protein increases with age in the mouse and rat brain. Neurobiol Aging 1991, 12:171-174.

79. Sloane JA, Hollander W, Rosene DL, Moss MB, Kemper T, Abraham CR: Astrocytic hypertrophy and altered GFAP degradation with age in subcortical white matter of the rhesus monkey. Brain Res 2000, 862:1-10.

80. Ownby RL: Neuroinflammation and cognitive aging. Curr Psychiatry Rep 2010, 12:39-45

81. Yirmiya R, Goshen I: Immune modulation of learning, memory, neural plasticity and neurogenesis. Brain Behav Immun 2011, 25:181-213.

82. Poon HF, Shepherd HM, Reed TT, Calabrese V, Stella AM, Pennisi G, Cai J, Pierce WM, Klein JB, Butterfield DA: Proteomics analysis provides insight into caloric restriction mediated oxidation and expression of brain proteins associated with age-related impaired cellular processes: Mitochondrial dysfunction, glutamate dysregulation and impaired protein synthesis. Neurobiol Aging 2006, 27:1020-1034.

83. Van Kirk CA, Vanguilder HD, Young M, Farley JA, Sonntag WE, Freeman WM: Age-related alterations in retinal neurovascular and inflammatory transcripts. Mol Vis 2011, 17:1261-1274.

84. Calabrese V, Scapagnini G, Ravagna A, Colombrita C, Spadaro F, Butterfield DA, Giuffrida Stella AM: Increased expression of heat shock proteins in rat brain during aging: relationship with mitochondrial function and glutathione redox state. Mech Ageing Dev 2004, 125:325-335.

85. Villeda SA, Luo J, Mosher Kl, Zou B, Britschgi M, Bieri G, Stan TM, Fainberg N, Ding Z, Eggel A, Lucin KM, CZirr E, Park JS, Couillard-Despres S, Aigner L, Li G, Peskind ER, Kaye JA, Quinn JF, Galasko DR, Xie XS, Rando TA, Wyss-Coray T: The ageing systemic milieu negatively regulates neurogenesis and cognitive function. Nature 2011, 477:90-94.

doi:10.1186/1742-2094-8-138

Cite this article as: VanGuilder et al:. Concurrent hippocampal induction of MHC II pathway components and glial activation with advanced aging is not correlated with cognitive impairment. Journal of

Neuroinflammation 2011 8:138.

\section{Submit your next manuscript to BioMed Central and take full advantage of:}

- Convenient online submission

- Thorough peer review

- No space constraints or color figure charges

- Immediate publication on acceptance

- Inclusion in PubMed, CAS, Scopus and Google Scholar

- Research which is freely available for redistribution 